J. Dairy Sci. 99:9611-9630

http://dx.doi.org/10.3168/jds.2016-10957

(C) American Dairy Science Association ${ }^{\circledR}, 2016$.

\title{
Predicting the distribution of whey protein fouling in a plate heat exchanger using the kinetic parameters of the thermal denaturation reaction of $\beta$-lactoglobulin and the bulk temperature profiles
}

\author{
P. Blanpain-Avet, ${ }^{1}$ C. André,† M. Khaldi, ${ }^{*}$ L. Bouvier, ${ }^{*}$ J. Petit,ł T. Six, ${ }^{*}$ R. Jeantet,§ T. Croguennec, $\S$ \\ and G. Delaplace* \\ *INRA, PIHM-UR638 (Processus aux Interfaces et Hygiène des Matériaux), UMET (Unité Matériaux Et Transformations) UMR CNRS 8207, 369, \\ rue Jules Guesde, BP 20039, 59651 Villeneuve d'Ascq Cedex, France \\ †HEI (Ecole des hautes Etudes d'Ingénieur), Département Chimie, Textiles et Process Innovants, 13, rue de Toul, 59046 Lille Cedex, France \\ łENSAIA-Université de Lorraine-Laboratoire d'Ingénierie des Biomolécules (LiBio), 2 avenue de la Forêt de Haye-TSA 40602, \\ 54518 Vandoeuvre-les-Nancy cedex, France \\ §Agrocampus Ouest, UMR 1253, STLO (Science et Technologie du Lait et de l'Oeuf), 65 rue de Saint-Brieuc, CS 84215, 35042 Rennes, France
}

\begin{abstract}
Fouling of plate heat exchangers (PHE) is a severe problem in the dairy industry, notably because the relationship between the build-up of protein fouling deposits and the chemical reactions taking place in the fouling solution has not yet been fully elucidated. Experiments were conducted at pilot scale in a corrugated PHE, and fouling deposits were generated using a model $\beta$-lactoglobulin ( $\beta$-LG) fouling solution for which the $\beta$-LG thermal denaturation reaction constants had been previously determined experimentally. Then 18 different bulk temperature profiles within the PHE were imposed. Analysis of the fouling runs shows that the dry deposit mass per channel versus the ratio $\mathrm{R}=$ $\mathrm{k}_{\mathrm{unf}} / \mathrm{k}_{\mathrm{agg}}$ (with $\mathrm{k}_{\mathrm{unf}}$ and $\mathrm{k}_{\mathrm{agg}}$ representing, respectively, the unfolding and aggregation rate constants computed from both the identification of the $\beta$-LG thermal denaturation process and knowledge of the imposed bulk temperature profile into the PHE channel) is able to gather reasonably well the experimental fouling mass data into a unique master curve. This type of representation of the results clearly shows that the heat-induced reactions (unfolding and aggregation) of the various $\beta-L G$ molecular species in the bulk fluid are essential to capture the trend of the fouling mass distribution inside a PHE. This investigation also illustrates unambiguously that the release of the unfolded $\beta-\mathrm{LG}$ (also called $\beta$-LG molten globule) within the bulk fluid (and the absence of its consumption in the form of aggregates) is a key phenomenon that controls the extent of protein fouling as well as its location inside the PHE.
\end{abstract}

Received January 28, 2016.

Accepted June 9, 2016.

${ }^{1}$ Corresponding author: blanpain-avet@lille.inra.fr
Key words: $\beta$-lactoglobulin, plate heat exchanger, fouling mass prediction, denaturation kinetic constant, concentration profile modelling

\section{INTRODUCTION}

Fouling of heat exchanger surfaces is a major industrial problem of milk processing plants, which lowers the heat transfer efficiency, shortens run times, and requires a daily cleaning (Bansal and Chen, 2006; Sadeghinezhad et al., 2013). This has consequences for the dairy industry both in terms of economics and sustainability. The reactor generally chosen to perform heating of milk is a plate heat exchanger (PHE) that features several favorable aspects compared with tubular heat exchangers or ohmic heaters. Fouling from milk-based fluids has been studied for several years in a variety of experimental geometries. Only a summary focusing on the topic of the most relevant fouling studies found in the literature will be presented here.

The key role played by $\beta$-LG has been recognized in most milk fouling studies for a type A (protein) fouling that takes place in the 75 to $110^{\circ} \mathrm{C}$ temperature range (Lalande et al., 1985; Changani et al., 1997; de Jong, 1997), as classified by Burton (1968). The predominant role of $\beta-L G$ has been connected to its thermal unfolding and aggregation process and thus depends strongly on protein structure (Blanpain-Avet et al., 2012; Petit et al., 2013; Wolz and Kulozik, 2015; Kerche et al., 2016; Wolz et al., 2016).

The following 5 steps possibly involved in the formation of fouling deposits have also been suggested (Burton, 1968):

1. Chemical reactions in the product (i.e., thermal denaturation), which convert one or more of its 
constituents into a form capable of being deposited on the surface.

Lalande et al. (1985) were the first to investigate the effect of $\beta$-LG denaturation in milk fouling and proposed that the heat denaturation of this globular protein results in the destabilization of the milk-based product and gives rise to foulant precursors which further lead to fouling on the heat transfer area. de Jong et al. (1992), who used a different reaction scheme compared with that employed in this study, used 2 consecutive reactions (unfolding and aggregation as also used by Bouvier et al., 2014) involving 2 independent kinetic constants. de Jong et al. (1992) applied the kinetics of the $\beta$-LG denaturation to analyze fouling in PHE; they found that the amount of deposit could be correlated with the concentration of unfolded $\beta-\mathrm{LG}$ and surface temperature.

It is today well established that 3 protein structures are involved in the course of the thermal denaturation: native $(\mathbf{N})$, unfolded (U), and aggregated (A) $\beta$-LG. At $\mathrm{pH}>6.8$ and for bulk temperature below $110^{\circ} \mathrm{C}$, which is our concern here, native $\beta$-LG $(\mathrm{N})$ unfolds to form the molten globule $\beta$-LG (U), exposing its reactive thiol $(-\mathrm{SH})$ group. This partially unfolded species can react in the product with native or other unfolded $\beta$-LG via thiol/disulfide interchange or thiol oxidation to form denatured $\beta$-LG (A) (Oldfield et al., 2005; De Wit, 2009), and this multistep scheme of the heat-induced denaturation of $\beta$-LG has been clearly illustrated in the investigation of Tolkach and Kulozik (2007) and is summarized in the original publication as shown by Figure 1.

2. Transportation of the product constituents (foulant or foulant precursor) to the surface depending on the flow regimen.

3. Adsorption of a layer of some fouling material to the surface to form an initial fouling layer.

Because fouling occurs at the solid/liquid interface, surface properties play an important role, as shown in the context of whey protein fouling (Boxler et al., 2014).

4. Deposition of other fouling materials or more of the same on the initial fouling layer.

The fouling material could stick on the initial layer and then could participate in deposit layer formation or form aggregates with other constituents into the bulk.

Nonnative forms of $\beta$-LG (unfolded and aggregated) were suggested to be the molecular species forming the deposit; however, findings reported in the literature were not always in agreement when discussing which species are involved in fouling build up and induced more fouling (Bansal and Chen, 2006; Sadeghinezhad et al., 2013). Blanpain-Avet et al. (2012) used recently the Raman spectroscopy method to show that aggregates (characterized by an irreversibly altered secondary structure) were not the cause of $\beta$-LG deposits.

5. Build-up of the fouling layer by deposition of further material, compensated by the mechanical removal of material through shearing forces caused by the flow of product across the deposited liquid interface.

The recent studies of Jimenez et al. (2013), Collier et al. (2015), and Khaldi et al. (2015a) have shown the role of the fouling fluid composition and the flow regimen in both deposit growth, adhesion, and modification of the structure of fouled layers.

The type and the composition of deposits were also widely investigated. For a temperature below $110^{\circ} \mathrm{C}$, the deposit is a type A (protein) fouling as classified by Burton (1968), consisting of 50 to $70 \mathrm{wt} \%$ proteins, 30 to $40 \mathrm{wt} \%$ minerals, and 4 to 8 wt $\%$ fat (Fickak et al., 2011). Depending on the fouling solution chemistry and temperature profile, deposit can contain other elements such as inorganic salts such as calcium phosphate

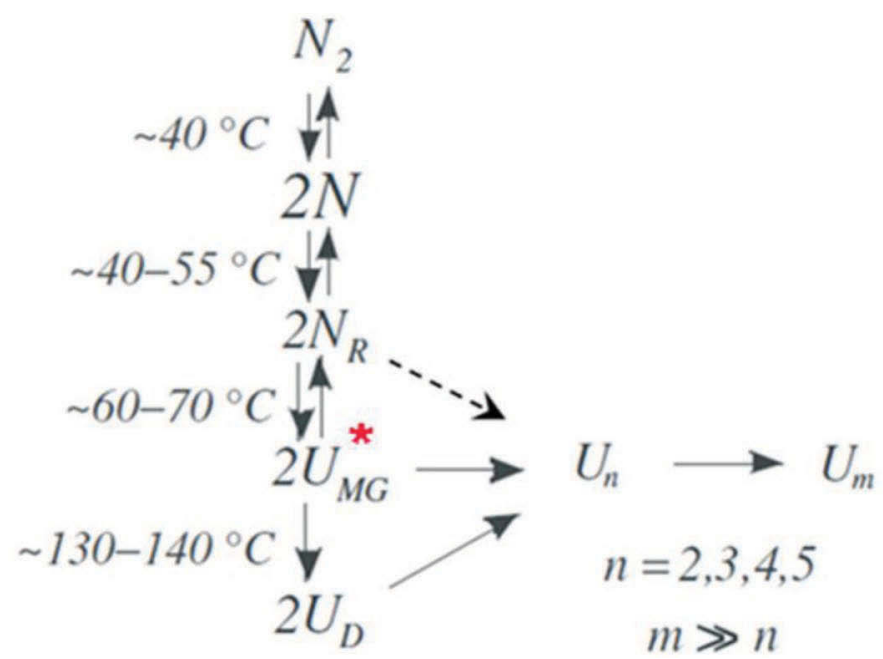

Figure 1. Multistage process characterizing $\beta-L G$ thermal denaturation/aggregation [extracted and adapted from Tolkach and Kulozik (2007)]. $\mathrm{U}_{\mathrm{MG}}{ }^{*}$ : molten globule state (reversible unfolding with a more flexible tertiary structure and a quasi-intact secondary structure); $\mathrm{N}_{2}$ : native dimer; $\mathrm{N}$ : native monomer; $\mathrm{N}_{\mathrm{R}}$ : R-state; $\mathrm{U}_{\mathrm{D}}$ : completely unfolded molecule; $\mathrm{U}_{\mathrm{n}}, \mathrm{U}_{\mathrm{m}}$ : polymerized $\beta$-LG molecules (aggregates); $\mathrm{n}$ : number of polymerized $\beta$-LG molecules associating the unfolded molecule; m: number of polymerized $\beta-\mathrm{LG}$ molecules forming $\beta-\mathrm{LG}$ aggregates. Color version available online. 
(Rosmaninho and Melo, 2006) or amorphous carbonate calcium (Jimenez et al., 2013). For a tubular heat exchanger, Belmar-Beiny and Fryer (1992) proposed a simple fouling model in which fouling was correlated with the volume of fluid hot enough to produce denatured and aggregated proteins. This result highlighted the importance of bulk reactions involved in denaturation, but does not pinpoint the nature of the chemical reactions in the product leading to fouling (unfolding, bulk aggregation, or both). Developing the idea proposed by Lalande et al. (1985) and Belmar-Beiny and Fryer (1992), Delplace and Leuliet (1995) established a correlation between the deposited dry mass and the native $\beta$-LG concentrations difference between the inlet and outlet of the channels; the proposed model shows unambiguously that the fouling rate depends on the concentration of the denatured $\beta-\mathrm{LG}$ molecules. Unfortunately, it did not provide the distribution of the unfolded and aggregated $\beta$-LG species along the PHE channel, and consequently failed to specify on how these 2 competitive/temperature dependent reactions govern fouling mechanisms.

In spite of such progress and although the relationship between bulk reactions and protein deposition has been investigated and reasonably clarified by a few authors (see, for example, the excellent review by Bansal and Chen, 2006), knowledge has to be improved to link the chemical reactions in the bulk (i.e., unfolding, aggregation of $\beta$-LG) and the extent of fouling. The present study endeavors to address some of these issues, making it crucial to collect accurate and reliable information on kinetic data related to the protein fouling solution used in regard to the process of $\beta-\mathrm{LG}$ unfolding and aggregation. The objective of this work was to show, for a given temperature profile inside the PHE, the appropriateness of using the ratio $\mathrm{R}\left(=\mathrm{k}_{\mathrm{unf}}\right.$ / $\mathrm{k}_{\mathrm{agg}}$ ) derived from the kinetic parameters determined at laboratory scale in predicting the distribution of the dry fouling deposit mass for various operating conditions within the PHE. For this purpose, a model whey protein isolate (WPI) fouling solution at a concentration of 6 wt $\%$ and at a fixed calcium content of 264 $\mathrm{mg} \cdot \mathrm{L}^{-1}$, for which the heat-induced $\beta$-LG unfolding/ aggregation process has been previously determined in the literature via a kinetic model (Petit et al., 2011), was selected as a model fouling solution.

\section{MATERIALS AND METHODS}

\section{WPI Fouling Solution}

The PHE was fouled using a reconstituted industrial WPI with an unknown pretreatment. The $\beta$-LG isolate (lot JE 001-8-415, Biopure) used in this study was pur- chased from Davisco Foods International Inc. (LeSueur, $\mathrm{MN}$ ) and consisted of approximately equal quantities of variants $\mathrm{A}$ and $\mathrm{B}$. The WPI powder was at a 6 wt \% concentration $(\mathrm{pH} 6.8)$ and at a $6.6 \mathrm{mM}$ ionic calcium content [anhydrous calcium chloride, $\mathrm{CaCl}_{2}, 96 \%$ purity (wt/wt), Prolabo, VWR, Radnor, PA]. Such an ionic calcium content (i.e., $264 \mathrm{mg} \cdot \mathrm{L}^{-1}$ of atom calcium content considering a molecular weight of $40.08 \mathrm{~g}$ per mol) was selected as the experimental program of this study was part of the research program GLOBULE (i.e., globule protein microstructure forming by direct heating systems, project entitled ANR-08-ALIA-08, Agence Nationale de la Recherche, France). The main aim of the GLOBULE research project was to develop a new heat treatment for testing globular whey proteins (such as $\beta$-LG) with a full control of the aggregate particle size and functionality. The protein concentration used (6 wt \%) is adequate to form a significant number of aggregates without $\beta-\mathrm{LG}$ gelation. It is noticed that the conformational state of $\beta-\mathrm{LG}$ within the WPI powder plays a dominant role in this study; it was thus measured experimentally by reverse-phase (RP) HPLC (using solutions of known concentrations of WPI powder) that native (nonaggregated) $\beta$-LG represented on average $89 \%$ (wt/wt) in the WPI powder. The WPI powder composition was as following: $89 \mathrm{wt} \% \beta-\mathrm{LG}$ (in weight percent on a dry basis), $\alpha-\mathrm{LA}<0.01 \mathrm{wt} \%$ ( $\beta$-LG and $\alpha$-LA were measured using RP-HPLC according to a methodology described by Petit et al., 2011), $0.1 \mathrm{wt}$ $\%$ fat, 1.9 wt $\%$ ash, and moisture 4.1 wt $\%$.

The experimental procedure of preparation of the fouling solution was the following: $15 \mathrm{~kg}$ of WPI powder was added to $250 \mathrm{~L}$ of deionized water maintained at $40^{\circ} \mathrm{C}$ in the launching tank (see Figure 2) and dissolving occurred during $2 \mathrm{~h}$ by gently stirring the solution followed by the addition of $187 \mathrm{~g}$ anhydrous $\mathrm{CaCl}_{2}$.

\section{Fouling Rig and Plate Heat Exchanger Configuration}

Fouling experiments were conducted using the fouling rig shown schematically in Figure 2. The fouling rig was composed of 3 distinct zones: preheating, heating, and holding zones. The preheating zone was composed of a tubular joule effect heater (JEH, $30 \mathrm{~kW}$, Actijoule, Actini SA, Maxilly-sur-Léman, France). The role of JEH is to raise the temperature of the fouling solution from $40^{\circ} \mathrm{C}$ to the PHE inlet temperature, $\mathrm{T}_{\mathrm{ip}}$, ranging from 50 to $70^{\circ} \mathrm{C}$. In the $\mathrm{JEH}$ zone, fouling was considered negligible as the denaturation temperature of $\beta$-LG is 74 to $76^{\circ} \mathrm{C}$ (Guérin et al., 2007). The heating zone is composed of a PHE in a counter-current configuration using hot water as the heating medium; a pilot-scale PHE in countercurrent configuration, supplied with a holder, was used to mimic industrial process conditions. 
A PHE was used to heat the fouling solution above the denaturation temperature (with a product outlet temperature, $\mathrm{T}_{\mathrm{op}}$, ranging from 70 to $95^{\circ} \mathrm{C}$ ). The $\mathrm{PHE}$ (VICARB, model V7, Alpha-Laval, France) involves 21 plates (each plate was $0.495 \mathrm{~m}$ long and $0.15 \mathrm{~m}$ wide, providing an exchange surface of $0.075 \mathrm{~m}^{2}$ ) forming 10 passes of one channel for both sides; the PHE was the investigated zone for the measurement of the fouling mass distribution. The distance noted $\mathrm{h}$ (or flow gap) between 2 consecutive plates was equal to $3.9 \times 10^{-3}$ $\mathrm{m}$. The plates had $35^{\circ}$ corrugation angle and the overall exchange surface was $1.43 \mathrm{~m}^{2}$. The holding zone was 20 $\mathrm{m}$ in length and made up of an assembly of insulated stainless steel tubular pipes of $23.4 \times 10^{-3} \mathrm{~m}$ internal diameter.

The other elements consisted of a storage tank of $300 \mathrm{~L}$ for the fouling solution whose temperature was controlled at $40 \pm 1^{\circ} \mathrm{C}$ using a tubular JEH $(15 \mathrm{~kW}$, Actijoule, Actini). The flow rate in the fouling rig was ensured by a volumetric pump (noted FP, Figure 2; type PL 20.12/40, PCM Pompes, France). The investigated zone for the deposited fouling mass was the PHE heating zone.

Stable process conditions were ensured by monitoring the heat exchanger inlet and outlet temperatures and flow rates using the following sensors (1) electromagnetic flowmeters for the flow rates (expected precision of $\pm 1 \%$ of the full scale), (2) platinum resistance probes for temperatures of all fluids $\left( \pm 0.2^{\circ} \mathrm{C}\right.$ for the temperature measurements). A differential pressure transducer (Schlumberger Type D, expected precision of $\pm 0.25 \%$ of the full scale) was also used for the PHE pressure drop. All parameters were collected via a data acquisition system (Agilent Technologies, Santa Clara, CA) with an acquisition period of $15 \mathrm{~s}$.

\section{Fouling Trial Protocol and Deposit Weighing}

Each fouling trial consisted of 5 stages:

1. initial stabilization of hydraulic and thermal parameters using reverse osmosis (RO) water circulation as the product in the pilot plant,

2. fouling run, with a fouling solution flow rate, $Q_{p}$, varying between 150 and $300 \mathrm{~L} \cdot \mathrm{h}^{-1}$ (turbulent flow regimen with $500<\operatorname{Re}<1,000)$. The Reynolds number in the PHE (Re) was computed based on physical properties of water, by assuming that the presence of a 6 wt \% WPI in water does not modify them significantly as reported by Delplace and Leuliet (1995) and Delplace et al. (1997); Reynolds number was defined by Re $=\rho \cdot \mathrm{v} \cdot \mathrm{D}_{\mathrm{h}} / \mu$, where the equivalent diameter $\mathrm{D}_{\mathrm{h}}$ is twice the average space $\mathrm{h}$ between 2 plates of the PHE $(\mathrm{h}=0.0039 \mathrm{~m})$.

3. first $\mathrm{RO}$ water rinse,

4. $\mathrm{NaOH}-\mathrm{HNO}_{3}$ cleaning procedure,

5. final $\mathrm{RO}$ water rinse.

Heat exchange conditions (e.g., temperature profile, heat transfer coefficient) were totally controlled by the PHE inlet parameters: product and hot fluid inlet temperatures, respectively, $\mathrm{T}_{\mathrm{ip}}$ and $\mathrm{T}_{\mathrm{ih}}$; and flow rates, respectively, $\mathrm{Q}_{\mathrm{p}}$ and $\mathrm{Q}_{\mathrm{h}}$. Consequently, it was possible to impose different temperature profiles (i.e., bulk temperature evolution with time). During the experiments, the inlet temperature of hot water was adjusted to ensure a constant outlet fouling solution temperature in the holding zone and a constant product temperature profile along the PHE as a function of time.

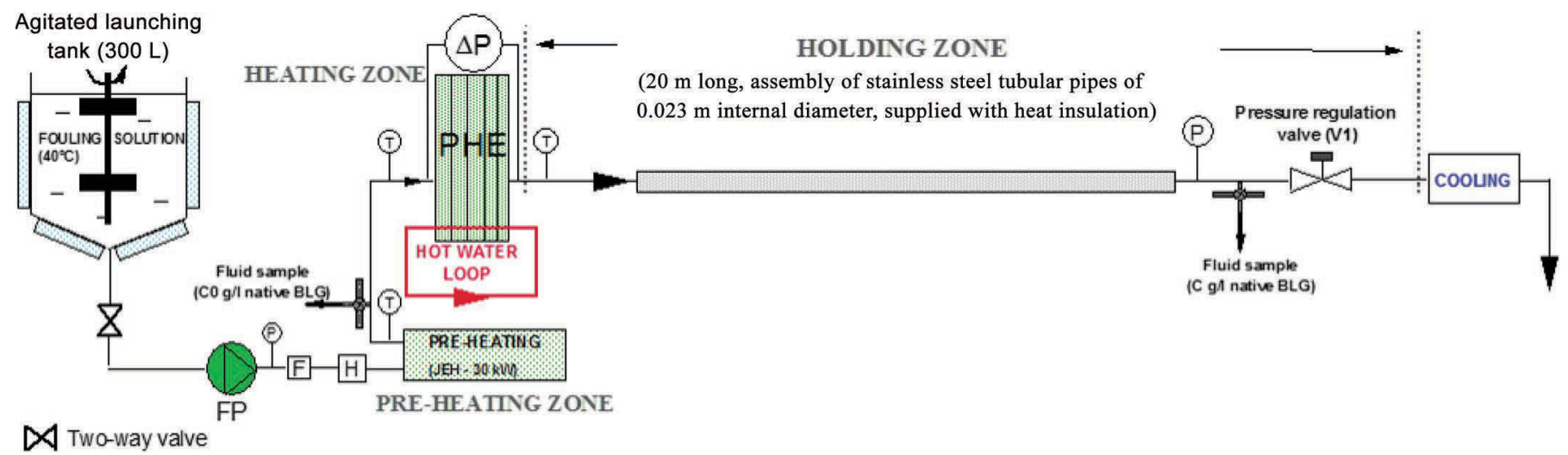

Figure 2. Schematic diagram of the experimental set-up used at pilot scale for the fouling experiments. $\Delta \mathrm{P}$ : differential pressure; PHE: plate heat exchanger; F: flowmeter; FP: feed pump; H: homogenizer; P: pressure gauge; T: temperature probe; V1: counter-pressure regulation valve: $\beta$-LG: $\beta$-lactoglobulin. Color version available online. 
Table 1. Experimental design used for the heat treatment, which consisted of the variation of 4 independent process parameters, that is, the product temperature at the plate heat exchanger $(\mathrm{PHE})$ outlet $\left(\mathrm{T}_{\mathrm{op}}\right)$, the mean residence time $(\tau)$, the temperature increase between the PHE inlet and outlet $\left(\Delta \mathrm{T}_{\mathrm{p}}\right)$, and the heat exchange efficiency $(\varepsilon)^{1}$

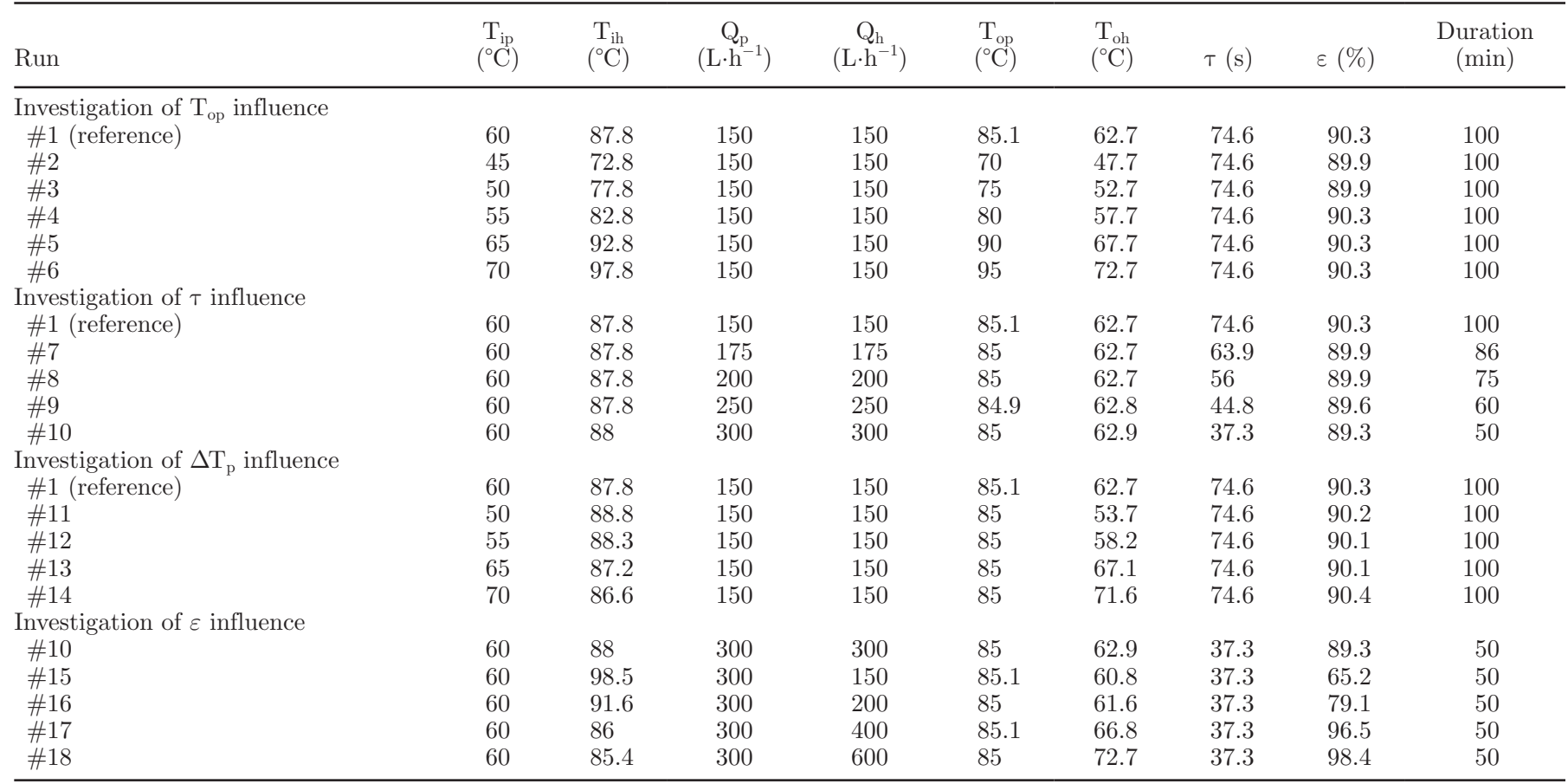

${ }^{1} \mathrm{~T}_{\mathrm{ip}}$ is the whey protein isolate (WPI) fouling solution temperature at the PHE inlet, $\mathrm{T}_{\mathrm{ih}}$ is the hot water temperature at the PHE inlet, $\mathrm{Q}_{\mathrm{p}}$ is the WPI fouling solution flow rate in the fouling stage, $\mathrm{Q}_{\mathrm{h}}$ is the hot water flow rate in the fouling stage, $\mathrm{T}_{\mathrm{oh}}$ is the hot water temperature at the PHE outlet.

In addition, the temperature in the holding section was maintained equal to $\mathrm{T}_{\mathrm{op}}$ in all experiments. The PHE inlet parameters associated with each fouling run are reported in Table 1. A total volume of $250 \mathrm{~L}$ of the WPI fouling solution was processed for each fouling run. As the product flow rate varied, run duration ranged from $50 \mathrm{~min}$ at $\mathrm{Q}_{\mathrm{p}}=300 \mathrm{~L} \cdot \mathrm{h}^{-1}$ to $100 \mathrm{~min}$ at $\mathrm{Q}_{\mathrm{p}}$ $=150 \mathrm{~L} \cdot \mathrm{h}^{-1}$. After reaching thermal equilibrium with $\mathrm{RO}$ water, the feed was switched from $\mathrm{RO}$ water to the fouling solution and the fouling stage was continued.

The fouling solution was not re-circulated once it was heated through the tubular JEH and PHE. After the fouling experiment, fouling solution was replaced by $\mathrm{RO}$ water at room temperature to decrease the PHE temperature and to stop the protein deposit growth. Following the first rinse, the PHE was dismantled and each fouled plate was carefully removed and stored at $70^{\circ} \mathrm{C}$ for $4 \mathrm{~h}$ to measure the dry weight of deposit onto the fouled plate.

Fouling mass in a single channel c (noted $\mathrm{m}_{\mathrm{dep}, \mathrm{c}}$ ) was determined by adding up the 2 deposit mass values obtained for the plates constituting the pass walls. The different channels (noted c) were numbered from 1 to 10 from the right (inlet) to the left (outlet) of the PHE.

\section{Numerical Evaluation of the Bulk and Wall Temperature Profiles Along the PHE}

For each experiment, the bulk temperature profile in the PHE was obtained by simulation with Sphere software (Danone, Paris, France), previously developed at the laboratory applying the numerical method proposed by René et al. (1991). Once the hydraulic and thermal performances of the considered PHE were implemented in this software, the bulk temperatures of both fluids at any location of the heat exchanger can be calculated from the knowledge of the inlet temperatures and flow rates of hot and cold fluids. The set of 18 bulk temperature profiles displayed in Figures 3(a) to $3(\mathrm{~d})$ was obtained by tuning the varying PHE inlet parameters gathered in Table 1 .

In Table 1 also appear the different output variables resulting from the varying PHE inlet parameters imposed, namely:

- the product temperature at the PHE outlet $\left(\mathrm{T}_{\mathrm{op}}\right)$,

- the temperature increase between the PHE inlet and outlet $\left(\Delta \mathrm{T}_{\mathrm{p}}=\mathrm{T}_{\mathrm{op}}-\mathrm{T}_{\mathrm{ip}}\right)$,

- the heat exchange efficiency $\left(\varepsilon=\frac{\mathrm{T}_{\mathrm{op}}-\mathrm{T}_{\mathrm{ip}}}{\mathrm{T}_{\mathrm{ih}}-\mathrm{T}_{\mathrm{ip}}}\right)$, 
- the mean residence time of the product in the $\operatorname{PHE}\left(\tau=\frac{\mathrm{V}_{\text {exch }}}{\mathrm{Q}_{\mathrm{p}}}\right.$, where $\left.\mathrm{V}_{\text {exch }}=3.1 \mathrm{~L}\right)$.

These variables $\left(\mathrm{T}_{\mathrm{op}}, \tau, \Delta \mathrm{T}_{\mathrm{p}}\right.$, and $\left.\varepsilon\right)$ are global output parameters that quantify how the heat and momentum transport in the PHE are affected by varying PHE inlet parameters. The output variables gathered in Table 1 will be used later in the article to discuss fouling mass deposit results.

In Figures 3(a) to 3(d), it could be observed that the temperature profiles have different shapes (linear or not), inducing different denaturation rates along the PHE. Note that the nominal process conditions of the reference experiment (\#1, Table 1$)$ were similar to industrial conditions: temperature increase from 60 to $85^{\circ} \mathrm{C}$ in the PHE in $74.6 \mathrm{~s}$ and then holding at $85^{\circ} \mathrm{C}$ for $16.6 \mathrm{~s}$.

Whatever the PHE inlet parameters imposed, a good agreement between experimental and simulated values was observed for the hot water and $\beta$-LG concentrate outlet bulk temperatures, which is an additional validation of the simulated temperature profiles provided by the Sphere software.

In Figure 3(a), the simulated plate wall temperature profiles (noted $\mathrm{T}_{\text {wall }}$ ) along the PHE have been also presented for run \#1 to run \#6. The plate wall temperature
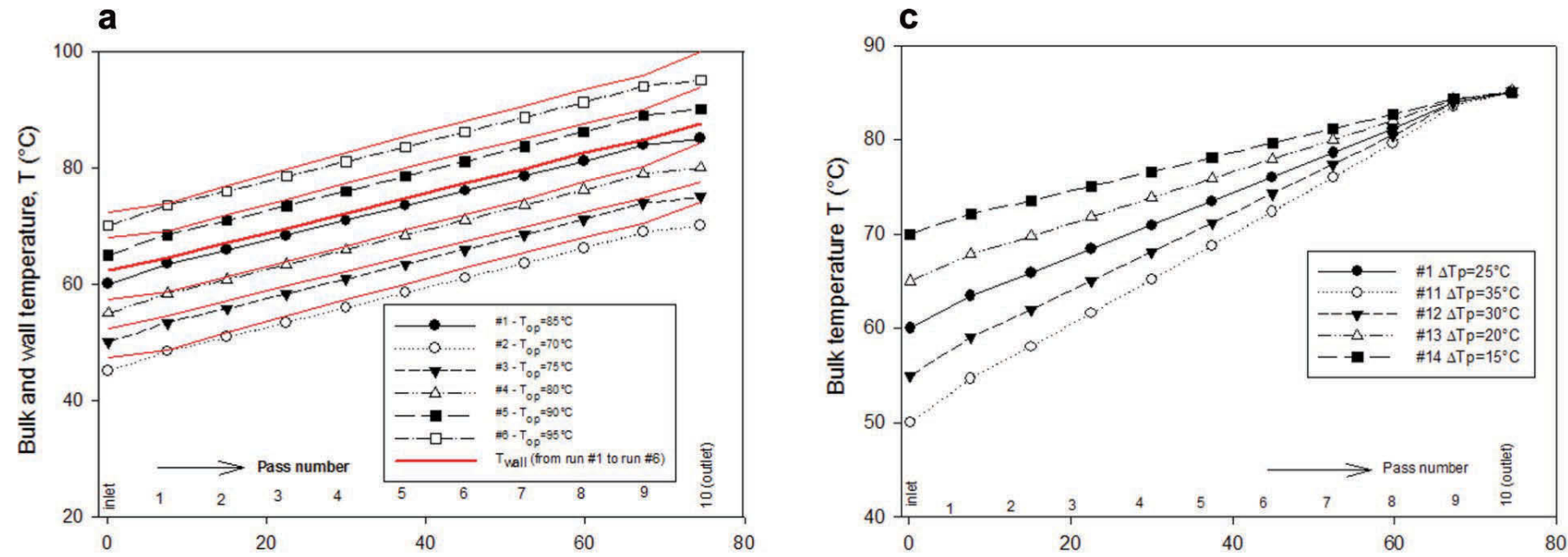

b
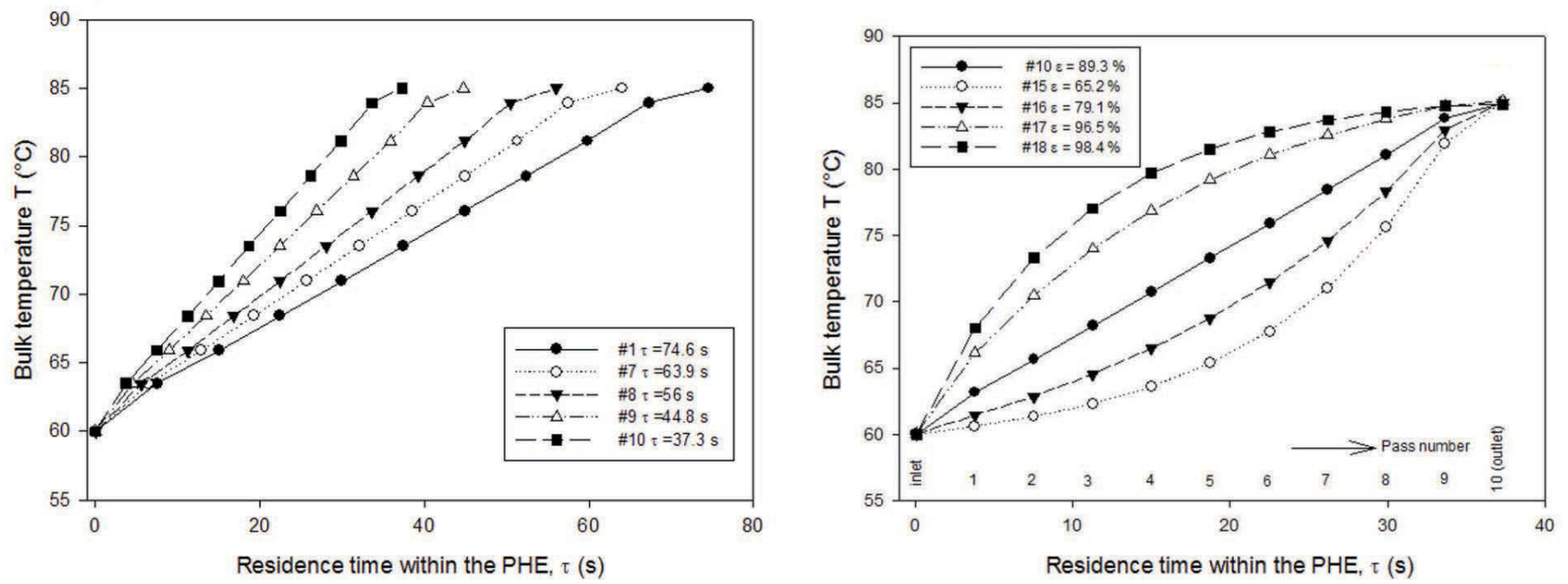

Figure 3. Calculated bulk temperature profiles inside the plate heat exchanger (PHE) using the Sphere software (René et al., 1991) for the 4 independent process parameters investigated [that is, $\mathrm{T}_{\mathrm{op}} ;(\mathrm{a}), \tau(\mathrm{b}), \Delta \mathrm{T}_{\mathrm{p}}(\mathrm{c})$, and $\varepsilon(\mathrm{d})$ ]. $\mathrm{T}_{\mathrm{op}}$ is the whey protein isolate (WPI) fouling solution temperature at the PHE outlet $\left({ }^{\circ} \mathrm{C}\right) ; \tau$ is the mean residence time of the WPI fouling solution in the PHE (s); $\Delta \mathrm{T}_{\mathrm{p}}$ is the WPI fouling solution temperature increase between the PHE inlet and outlet $\left(\mathrm{T}_{\mathrm{op}}-\mathrm{T}_{\mathrm{ip}} ;{ }^{\circ} \mathrm{C}\right)$, where $\mathrm{T}_{\mathrm{ip}}$ is the WPI fouling solution temperature at the PHE inlet; $\varepsilon$ is the heat exchange efficiency on the product side, dimensionless. Bulk temperature is plotted against the mean residence time $(\tau)$ and the pass number (ith pass of the PHE) within the PHE. Color version available online. 
of each run has been evaluated according to the method described by Toyoda et al. (1994) in the absence of fouling. From Figure 3(a) analysis, it appears that for each case, $\mathrm{T}_{\text {wall }}$ values are very close to the bulk fluid temperature $\left(T_{b}\right)$ values along the PHE (the percent variation between $T_{\text {wall }}$ and $T_{b}$ in each pass does not exceed $+0.5 \%$, if we except the 2 values at the PHE inlet and outlet for which percent variation can reach up to 4\%). A similar magnitude of variation between bulk and plate wall temperature profiles was obtained for the other runs. Consequently, for sake of simplicity, it was decided (1) to consider, for the numerical simulation of the population balance, that the totality of the volume of fluid in the channel is submitted to a bulk temperature profile, and (2) to take no account of the slight temperature gradient between the surface and the bulk, which could modify the population balance (i.e., $\beta$-LG species $\mathrm{N}$, U, and A).

\section{Determination of the Kinetic Parameters}

Experimental Thermal Denaturation Tests. Thermal denaturation tests on samples of the model fouling solution in the 68 to $96^{\circ} \mathrm{C}$ holding temperature range were conducted at laboratory scale, according to the methodology wholly described by Petit et al. (2011). Briefly, this method consists in submitting samples of the model fouling solutions (volume of $1.4 \mathrm{~mL}$ per sample) to 2 subsequent temperature gradual increases by submerging polypropylene tubes (containing static samples of the model fouling solution) in consecutive water baths. The first temperature increase is at $60^{\circ} \mathrm{C}$ (i.e., under the denaturation temperature of $\beta$-LG equal to 74 to $76^{\circ} \mathrm{C}$, Guérin et al., 2007), whereas the second one is tuned at the desired holding temperature. Once the desired holding temperature was reached, the time was set to zero and samples were progressively taken off the bath at different residence times and cooled down quickly below $60^{\circ} \mathrm{C}$ using an ice water bath.

HPLC Analysis. The concentration of soluble (native) $\beta$-LG species (and the resulting concentration of aggregated $\beta-\mathrm{LG}$ ) in each sample versus time was evaluated by analyzing each sample using RP-HPLC. The RP-HPLC analysis is carried out after precipitation of the aggregated protein at $\mathrm{pH} 4.6$ (using the addition of $1 M$ acetic acid) and its removal by centrifugation $\left(9,056 \times g\right.$ for $30 \mathrm{~min}$ at $\left.4^{\circ} \mathrm{C}\right)$. The chromatographic system (Waters, Milford, MA) included a 717 Plus autosampler, a 616 quadratic pump system, a Jones Model 7971 column oven, a CLHP ACE $300 \AA$ C4 separation column and the associated guard column (Advanced Chromatography Technologies, Aberdeen, UK), a 486 UV-visible spectrophotometer, and an acquisition soft- ware (Millenium 3.2, Waters). The mobile phases used in HPLC were $0.1 \%$ (vol/vol) trifluoroacetic acid (99\%, Acros Organics, Thermo Fisher Scientific, Waltham, MA) in Milli-Q water, and $0.1 \%$ trifluoroacetic acid in a mixture of $80 \%$ acetonitrile (HPLC grade, Thermo Fisher Scientific) and 20\% Milli-Q water.

The HPLC analyses were carried out using the following conditions: flow rate $1 \mathrm{~mL} \cdot \mathrm{min}^{-1}$, injection volume $20 \mu \mathrm{L}$, temperature $40^{\circ} \mathrm{C}$, elution of the proteins using a gradient of acetonitrile, and detection of the eluted proteins at a wavelength of $214 \mathrm{~nm}$. Analyses were repeated 3 times for each standard or sample. Calibration standards in the range from 0.5 to $4 \mathrm{~g} \cdot \mathrm{L}^{-1}$ were prepared by dissolving a known amount of lyophilized $\beta-\mathrm{LG}$ powder (purity minimum $90 \%$ for $\beta-\mathrm{LG}$, purchased from Sigma-Aldrich, Saint-Quentin-Fallavier, France) in Milli-Q water. For each experiment, sample concentrations were calculated by averaging the 3 measured chromatographic areas and converting this area value into a native $\beta$-LG concentration using a HPLC calibration curve previously determined.

Determination of the Denaturation Reaction Order (n) and the Formal Denaturation Rate Constant $\left(k_{n}\right)$. The reaction scheme used in this study to describe the heat-induced denaturation reaction of $\beta-L G$ is derived from the work of Tolkach and Kulozik (2007), that is:

$$
\mathrm{S} \stackrel{\mathrm{k}_{\mathrm{n}}}{\longrightarrow} \mathrm{A},
$$

with $\mathrm{S}$ representing the total soluble $\beta-\mathrm{LG}$ species (i.e., nonaggregated $\beta-\mathrm{LG}$ as measured by HPLC in the supernatant of the heated solution assayed following the precipitation at $\mathrm{pH} 4.6$ ) and $\mathrm{A}$ representing the aggregated (insoluble) $\beta$-LG; $k_{n}$ is the formal denaturation rate constant for an overall reaction order equal to $n$ $\left(\mathrm{k}_{\mathrm{n}}\right.$ is expressed as $\left.\mathrm{g}^{1-\mathrm{n}} \cdot \mathrm{L}^{\mathrm{n}-1} \cdot \mathrm{s}^{-1}\right)$.

Consequently, the denaturation kinetics concerning the transformation of soluble species into insoluble species could be defined by the general rate Equation [2]:

$$
\frac{\mathrm{dC}_{\mathrm{s}}}{\mathrm{dt}}=-\mathrm{k}_{\mathrm{n}} \mathrm{C}_{\mathrm{s}}^{\mathrm{n}}
$$

where $\mathrm{C}_{\mathrm{s}}$ is the total soluble (nonaggregated) $\beta$-LG concentration $\left(\mathrm{g} \cdot \mathrm{L}^{-1}\right), \mathrm{n}$ is the heat-induced denaturation reaction order (dimensionless), and $\mathrm{t}$ is the time (s).

Resolution of Equation [2] provides different $\mathrm{C}_{\mathrm{s}}$ expressions depending on whether the reaction order value is equal to 1 or not (see Petit et al., 2011).

$$
\text { For } n \neq 1, C_{S}(t)=C_{S 0}\left(1+(n-1) k_{n} C_{S 0}^{n-1} t\right)^{1 / 1-n} \text {. }
$$




$$
\text { And for } \mathrm{n}=1, \ln \left(\mathrm{C}_{\mathrm{s}}(\mathrm{t}) / \mathrm{C}_{\mathrm{s} 0}\right)=-\mathrm{k}_{\mathrm{n}} \mathrm{C}_{\mathrm{s} 0}{ }^{\mathrm{n}-1} \mathrm{t} \text {, }
$$

with $\mathrm{C}_{\mathrm{S} 0}$ is the initial (time zero) $\beta$-LG total soluble concentration $\left(\mathrm{g} \cdot \mathrm{L}^{-1}\right)$.

The value of $n$ was varied from 1 to 2 (in steps of 0.1 ). Then, for $n \neq 1$ (or $\ln \left(\mathrm{C}_{\mathrm{s}}(\mathrm{t}) / \mathrm{C}_{\mathrm{s} 0}\right)$ for $\mathrm{n}=1$ ) was plotted as a function of time. The reaction order that gives the best fit (according to the criterion of a Pearson product moment correlation coefficient close to $\mathrm{r}=$ 1) of the experimental data was retained [it was found for all experiments that $\mathrm{n}=1.5$, as found for instance by Akkerman et al. (2016) who used different heating strategies]. Finally, applying a denaturation reaction order of $\mathrm{n}=1.5$ for the whole range of the holding temperatures investigated, the corresponding denaturation rate constant $\left(\mathrm{k}_{\mathrm{n}}=\mathrm{k}_{1.5}\right)$ for each holding temperature was deduced from the slope of a linear regression.

Arrhenius Plot and Determination of the Reaction Rate Constants ( $\boldsymbol{k}_{\text {unf }}$ and $\boldsymbol{k}_{\text {agg }}$ ). To observe the temperature dependency of the formal denaturation rate constant, an Arrhenius plot involving the variation of the logarithm of $\mathrm{k}_{1.5}$ with the inverse holding temperature $\left({ }^{\circ} \mathrm{C}\right), 1 / \mathrm{T}$, (see Figure 4 ) was built. The Arrhenius plot exhibited 2 zones separated by a critical (or bend-) temperature (noted $\mathrm{T}_{\text {critical }}$ ) close to $78^{\circ} \mathrm{C}$.

When the temperature dependence of the formal denaturation rate constant is described by Equation [5], the slope break delimitates 2 temperature ranges with different values for $\ln \left(\mathrm{k}_{\mathrm{n}}{ }^{0}\right)$ and $\mathrm{E}_{\mathrm{A}}$ :

$$
\ln \left(\mathrm{k}_{\mathrm{n}}\right)=\ln \left(\mathrm{k}_{\mathrm{n}}^{0}\right)-\frac{\mathrm{E}_{\mathrm{A}}}{\mathrm{R}_{\mathrm{gas}} \mathrm{T}}
$$

where $\mathrm{k}_{\mathrm{n}}{ }^{0}$ is the denaturation frequency factor (also called preexponential factor), $\mathrm{E}_{\mathrm{A}}$ is the denaturation activation energy, $R_{\text {gas }}$ is the universal gas constant, and $\mathrm{T}$ is the holding temperature.

Considering the fact that the Arrhenius plot $\left(k_{n}\right.$ versus $1 / \mathrm{T}$ curve) could not be described by a unique thermal dependency, it was chosen to assume [similar to Tolkach and Kulozik (2007) and to Petit et al. (2011)] that the denaturation process of $\beta-\mathrm{LG}$ is not as trivial as a 2 -state process (i.e., $\mathrm{S} \rightarrow \mathrm{A}$, see Equation [1]); it has been thus assumed here to be a 3 -state process [represented in Figure 5, as proposed by Tolkach and Kulozik (2007)].

The advantage of using the kinetic model of Tolkach and Kulozik (2007) is that it takes account of the existence of the $\beta$-LG molten globule and also a mathematical interpretation of the occurrence of the sharp bend on the Arrhenius plot is provided. Below the critical temperature, the denaturation reaction is limited by the unfolding reaction, whereas above the critical temperature, $\beta-\mathrm{LG}$ denaturation is limited by the aggregation reaction (Tolkach and Kulozik, 2007; Petit et al., 2011).

Consequently, linear regressions of the experimental values in the 2 temperature ranges allowed us to determine the kinetic parameters (frequency factors and activation energies) related to the unfolding (Equation [6]) and aggregation (Equation [7]) phenomena (Petit et al., 2011):

$$
\ln \left(\mathrm{k}_{\text {unf }}\right)=\ln \left(\mathrm{k}_{0, \text { unf }}\right)-\frac{\mathrm{E}_{\mathrm{a}, \mathrm{unf}}}{\mathrm{R}_{\text {gas }} \cdot \mathrm{T}},
$$

where $\mathrm{k}_{\mathrm{unf}}$ is the unfolding rate constant depending on $\mathrm{n}\left(\mathrm{g}^{1-\mathrm{n}} \cdot \mathrm{L}^{\mathrm{n}-1} \cdot \mathrm{s}^{-1}\right), \mathrm{k}_{0, \text { unf }}$ is the unfolding frequency factor $\left(\mathrm{g}^{1-\mathrm{n}} \cdot \mathrm{L}^{\mathrm{n}-1} \cdot \mathrm{s}^{-1}\right)$, and $\mathrm{E}_{\mathrm{a} \text {, unf }}$ is the unfolding activation energy $\left(\mathrm{J} \cdot \mathrm{mol}^{-1}\right)$; and

$$
\ln \left(\mathrm{k}_{\mathrm{agg}}\right)=\ln \left(\mathrm{k}_{0, \mathrm{agg}}\right)-\frac{\mathrm{E}_{\mathrm{a}, \mathrm{agg}}}{\mathrm{R}_{\mathrm{gas}} \cdot \mathrm{T}},
$$

where $\mathrm{k}_{\mathrm{agg}}$ is the aggregation rate constant depending on $\mathrm{n}\left(\mathrm{g}^{\mathrm{a}-\mathrm{n}} \cdot \mathrm{L}^{\mathrm{n}-1} \cdot \mathrm{s}^{-1}\right), \mathrm{k}_{0, \text { agg }}$ is the aggregation frequency factor $\left(\mathrm{g}^{1-\mathrm{n}} \cdot \mathrm{L}^{\mathrm{n}-1} \cdot \mathrm{s}^{-1}\right)$, and $\mathrm{E}_{\mathrm{a}, \mathrm{agg}}$ is the aggregation activation energy $\left(\mathrm{J} \cdot \mathrm{mol}^{-1}\right)$.

Table 2 presents the kinetic parameters derived from Equations [6] and [7]. These kinetic parameters $\left(\mathrm{k}_{0, \text { unf }}\right.$, $\mathrm{E}_{\mathrm{a} \text {,unf }}, \mathrm{k}_{0, \text { agg }}, \mathrm{E}_{\mathrm{a}, \text { agg }}$ ) fully define the $\beta$-LG denaturation in each temperature range and were used to calculate the concentration of the different $\beta-\mathrm{LG}$ species $(\mathrm{N}, \mathrm{U}$, and A) induced by different temperatures profile as illustrated later in this paper.

A brief comparison of the calculated $\mathrm{E}_{\mathrm{a}}$ values to those found in the literature is presented below. Concerning the unfolding reaction, our values are consistent with those found by Tolkach and Kulozik (2007), Dannenberg and Kessler (1986), and de Jong et al. (2002); in the aggregation-limited range, as expected due to a relatively large $\beta$-LG concentration (6 wt \%), our $\mathrm{E}_{\mathrm{a}}$ values are close to those found by Tolkach and Kulozik (2007), Dannenberg and Kessler (1986), and de Jong et al. (2002), albeit a little greater. Compared with the results obtained by Khaldi et al. (2015b), our values are significantly lower; this is likely to be due to the fact that the break is less visible.

Calculation of the $\beta-L G$ Unfolding Degree $(\alpha)$. The formation of the molten globule state (U) during the thermal treatment of protein solutions can 


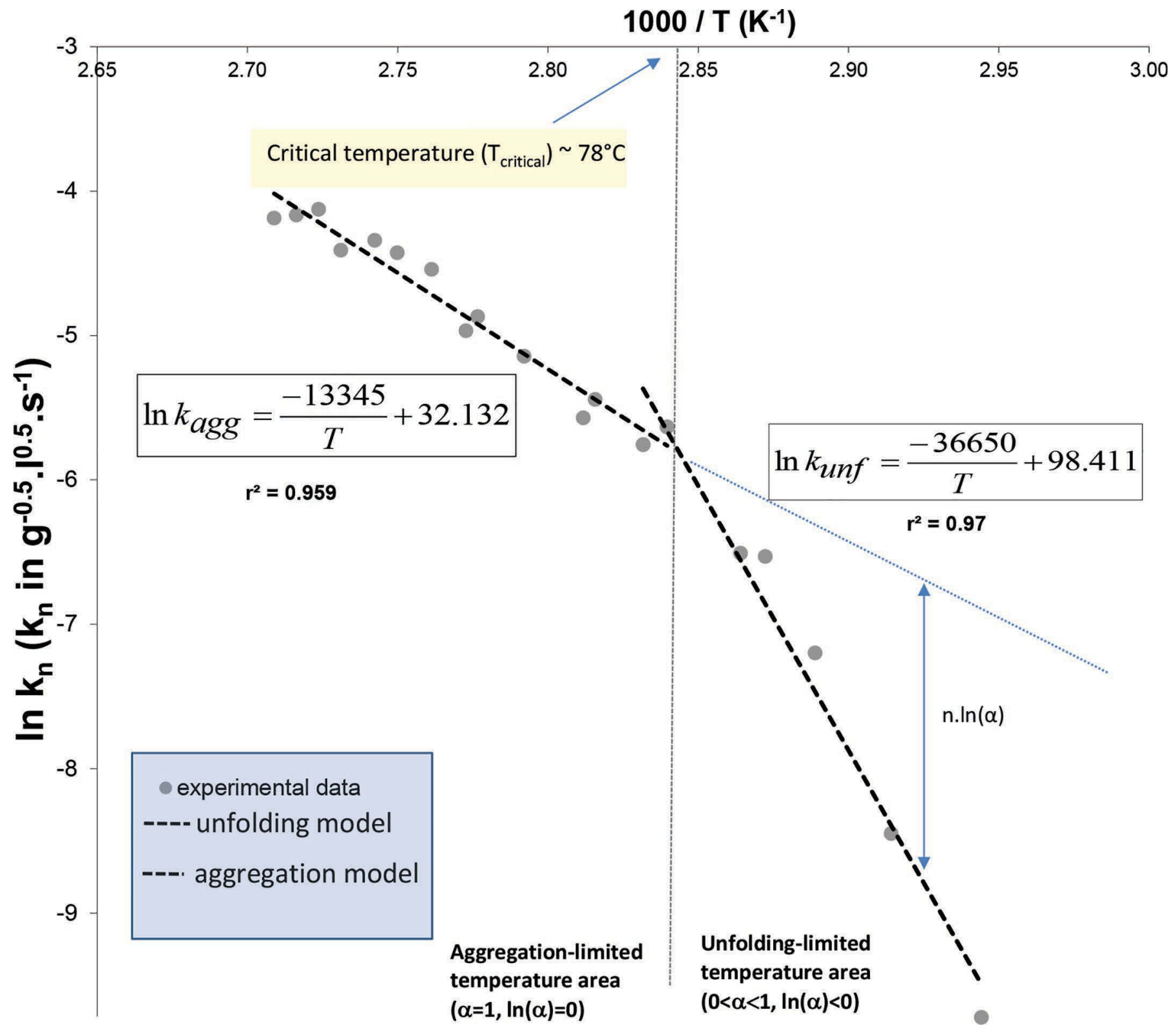

Figure 4. Arrhenius plot for the $\beta$-lactoglobulin $(\beta-\mathrm{LG})$ thermal denaturation reaction with a $\mathrm{n}=1.5$ reaction order, for the 6 wt $\%$ $\beta$-LG fouling solution used at $6.6 \mathrm{~m} M$ calcium content [adapted from Petit et al. (2011)]. Solid and dashed lines correspond to the linear regressions of experimental data. $\mathrm{k}_{\mathrm{n}}$ is the formal $\beta$-LG denaturation rate constant for a reaction order equal to $\mathrm{n}$, as defined by Equation [2] $\left(\mathrm{kg}^{1-\mathrm{n}} \cdot \mathrm{m}^{-3(1-\mathrm{n})} \cdot \mathrm{s}^{-1}\right) ; \mathrm{T}_{\text {critical }}$ is the critical temperature of the Arrhenius plot, delimiting the unfolding-limited range and the aggregation-limited range $\left({ }^{\circ} \mathrm{C}\right) ; \mathrm{k}_{\mathrm{agg}}$ is the aggregation reaction rate constant $\left(\mathrm{kg}^{1-n} \cdot \mathrm{m}^{-3(1-\mathrm{n})} \cdot \mathrm{s}^{-1}\right) ; \mathrm{k}_{\text {unf }}$ is the unfolding reaction rate constant $\left(\mathrm{kg}^{1-\mathrm{n}} \cdot \mathrm{m}^{-3(1-\mathrm{n})} \cdot \mathrm{s}^{-1}\right) ; \alpha$ is the unfolding degree of $\beta$-LG. Color version available online.

be characterized by an equilibrium between native $(\mathrm{N})$ and partially unfolded $\beta$-LG, which quantitatively can be described by an unfolding degree $\alpha$ (Tolkach and Kulozik, 2007):

$$
\alpha=\frac{\mathrm{C}_{\mathrm{U}}}{\mathrm{C}_{\mathrm{N}}+\mathrm{C}_{\mathrm{U}}}=\frac{\mathrm{C}_{\mathrm{U}}}{\mathrm{C}_{\mathrm{S}}} .
$$

The concentration of unfolded $\beta$-LG $\left(\mathrm{C}_{\mathrm{U}}\right)$ and native $\beta$-LG $\left(\mathrm{C}_{\mathrm{N}}\right)$ during the heat treatment can be derived from Equation [8]:

$$
\mathrm{C}_{\mathrm{U}}=\alpha \cdot \mathrm{C}_{\mathrm{s}} \text {, }
$$

and consequently, 


\section{Summary of the Tolkach and Kulozik (2007) kinetic model}

\section{Experimental approach}

\section{$S \stackrel{k_{n}}{\longrightarrow} A$}

a) Determination of the concentration of species $\mathrm{S}$ (soluble) and A (aggregated) :

$$
\begin{aligned}
& C_{S}(t)=C_{S}{ }^{\circ}\left(1+(n-1) k_{n} C_{S}{ }^{\circ n-1} t\right)^{1 / 1-n} \\
& C_{A}(t)=C_{S}{ }^{\circ}-C_{S}(t)
\end{aligned}
$$

b) Identification of the two regions due to a discontinuity in the Arrhenius plot resulting in a blend :

$$
\left\{\begin{array}{l}
T \leq T_{C}: k_{\text {unf }}(T)=k_{n}(T) \\
T>T_{C}: k_{\text {agg }}(T)=k_{n}(T)
\end{array}\right.
$$

\section{Proposed kinetic scheme}

Equilibrium between $\mathrm{N}$ and $\mathrm{U}$, governed by the parameter $\alpha$ followed by the aggregation reaction $\left(\mathrm{k}_{\mathrm{agg}}\right)$, i.e.,

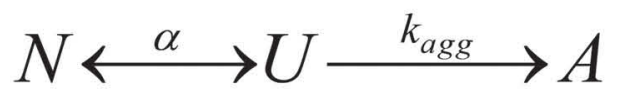

a) Determination of the unfolding degree :

$$
\left\{\begin{array}{l}
T \leq T_{C}: \alpha=\exp \left(\frac{\ln \left(k_{\text {unf }}\right)-\ln \left(k_{\text {agg }}\right)}{n}\right) \\
T>T_{C}: \alpha=1
\end{array}\right.
$$

b) Calculation of the concentration of species $\mathrm{N}$ (native) and $\mathrm{U}$ (unfolded) :

$$
\begin{aligned}
& C_{U}(t)=\alpha \cdot C_{S}(t) \\
& C_{N}(t)=(1-\alpha) \cdot C_{S}(t)
\end{aligned}
$$

Figure 5. Schematic diagram of the reaction scheme selected for the thermal denaturation/aggregation process of $\beta$-lactoglobulin ( $\beta$-LG). $\mathrm{S}$ is the total (time-dependent) soluble (i.e., nonaggregated) $\beta$-LG species quantified by reverse-phase HPLC; A is the aggregated $\beta$-LG; $\mathrm{C}_{\mathrm{S}}$ is the concentration of total soluble (i.e., nonaggregated) $\beta-\mathrm{LG}$ (noted $\mathrm{S}$ ) (i.e., $\mathrm{C}_{\mathrm{S}}=\mathrm{C}_{\mathrm{N}}+\mathrm{C}_{\mathrm{U}}$ ) $\left(\mathrm{kg} \cdot \mathrm{m}^{-3}\right.$ ); $\mathrm{C}_{\mathrm{A}}$ is the calculated concentration of aggregated $\beta$-LG (A) along the plate heat exchanger (PHE) channels $\left(\mathrm{kg} \cdot \mathrm{m}^{-3}\right) ; \mathrm{T}$ is the temperature $\left({ }^{\circ} \mathrm{C}\right) ; \mathrm{T}_{\mathrm{c}}$ is the critical temperature of the Arrhenius plot, delimiting the unfolded-limited range and the aggregation-limited range $\left({ }^{\circ} \mathrm{C}\right)$; native $(\mathrm{N})$, unfolded $(\mathrm{U})$, and aggregated (A); $\alpha$ is the unfolding degree of $\beta$-LG; $\mathrm{k}_{\text {unf }}$ is the unfolding reaction rate constant $\left(\mathrm{kg}^{1-\mathrm{n}} \cdot \mathrm{m}^{-3(1-\mathrm{n})} \cdot \mathrm{s}^{-1}\right)$; $\mathrm{k}_{\mathrm{agg}}$ is the aggregation reaction rate constant $\left(\mathrm{kg}^{1-\mathrm{n}} \cdot \mathrm{m}^{-3(1-\mathrm{n})} \cdot \mathrm{s}^{-1}\right) ; \mathrm{k}_{\mathrm{n}}$ is the formal $\beta-\mathrm{LG}$ denaturation rate constant for a reaction order equal to $\mathrm{n}$, as defined by Equation [2] $\left(\mathrm{kg}^{1-\mathrm{n}} \cdot \mathrm{m}^{-3(1-\mathrm{n})} \cdot \mathrm{s}^{-1}\right) ; \mathrm{C}_{\mathrm{U}}$ is the calculated concentration of unfolded $\beta$-LG $(\mathrm{U})$ along the PHE channels $\left(\mathrm{kg} \cdot \mathrm{m}^{-3}\right) ; \mathrm{C}_{\mathrm{N}}$ is the calculated concentration of native $\beta$-LG $(\mathrm{N})$ along the PHE channels $\left(\mathrm{kg} \cdot \mathrm{m}^{-3}\right)$. 
Table 2. Kinetic parameters used for the protein reaction scheme adopted in the prediction of fouling (unfolding and aggregation reactions of $\beta$-lactoglobulin ( $\beta$-LG; Petit et al., 2011) ${ }^{1}$

\begin{tabular}{llcc}
\hline Reaction & Variable & Value & Units \\
\hline Unfolding & $\mathrm{E}_{\mathrm{a}, \text { unf }}$ & 304.7 & $\mathrm{~kJ} \cdot \mathrm{mol}^{-1}$ \\
& $\ln \left(\mathrm{k}_{0, \text { unf }}\right)$ & 98.4 & $(-)$ \\
& Reaction order & 1.5 & $(-)$ \\
Aggregation & $\mathrm{E}_{\mathrm{a}, \text { agg }}$ & 111 & $\mathrm{~kJ} \cdot \mathrm{mol}^{-1}$ \\
& $\ln \left(\mathrm{k}_{0, \mathrm{agg}}\right)$ & 32.1 & $(-)$ \\
& Reaction order & 1.5 & $(-)$ \\
\hline
\end{tabular}

${ }^{1} \mathrm{E}_{\mathrm{a}, \text { unf }}$ is the $\beta$-LG unfolding activation energy $\left(\mathrm{J} \cdot \mathrm{mol}^{-1}\right), \mathrm{k}_{0, \text { unf }}$ is the unfolding pre-exponential factor $\left(\mathrm{kg}^{1-\mathrm{n}} \cdot \mathrm{m}^{-3(1-\mathrm{n})} \cdot \mathrm{s}^{-1}\right), \mathrm{E}_{\mathrm{a}, \mathrm{agg}}$ is the $\beta-\mathrm{LG}$ aggregation activation energy $\left(\mathrm{J} \cdot \mathrm{mol}^{-1}\right), \mathrm{k}_{0, \mathrm{agg}}$ is the aggregation preexponential factor $\left(\mathrm{kg}^{1-\mathrm{n}} \cdot \mathrm{m}^{-3(1-\mathrm{n})} \cdot \mathrm{s}^{-1}\right)$.

$$
\mathrm{C}_{\mathrm{N}}=(1-\alpha) \cdot \mathrm{C}_{\mathrm{s}}
$$

The parameter $\alpha$ can be calculated from the formal velocity constant $\mathrm{k}_{\mathrm{n}}$ and the aggregation rate constant $\mathrm{k}_{\text {agg }}$ extrapolated into the unfolded limited area, as shown by Tolkach and Kulozik (2007):

$$
\alpha=\exp \left(\frac{\ln \left(\mathrm{k}_{\mathrm{n}}\right)-\ln \left(\mathrm{k}_{\mathrm{agg}}\right)}{\mathrm{n}}\right) .
$$

Table 3 shows a calculation of the unfolding degree $\alpha$ according to Equation [11] with $\mathrm{n}=1.5$ using the formal denaturation rate constant (i.e., $\mathrm{k}_{1.5}$ ) in the 45 to $110^{\circ} \mathrm{C}$ temperature range. This model can be summarized by Figure 5 .

\section{Determination of the Concentration Profiles of the $\beta-L G$ Species $(N, U, A)$}

The numerical simulation of the concentration profiles of the different $\beta$-LG species within the PHE [i.e., $\mathrm{C}_{\mathrm{N}}, \mathrm{C}_{\mathrm{U}}, \mathrm{C}_{\mathrm{A}}=\mathrm{f}$ (mean residence time, $\tau$ )] was computed from the knowledge of the following:

(i) the kinetics of the heat-induced $\beta$-LG unfolding and aggregation reactions (measured in the range of $68-96^{\circ} \mathrm{C}$ ), which is schematized by the set of reversible consecutive reactions presented in Figure 5 (Tolkach and Kulozik, 2007);

(ii) the simulated profile of the bulk fluid temperature within the PHE for given PHE inlet parameters in the clean steady-state.

More precisely, the evaluation of the concentration profile of the various $\beta$-LG species (i.e., native $\mathrm{N}$, unfolded U, and aggregated A) along the PHE was obtained using the Runge-Kutta 4 numerical method to solve Equations [2], [6], [7], [8], [9], [10], and [11]. The concentration at any mean residence time (noted $\tau$ ) of the irreversibly aggregated $\beta-\mathrm{LG}\left(\mathrm{C}_{\mathrm{A}}\right)$ can be calculated as the difference between the calculated concentration of the total soluble species (i.e., $\mathrm{C}_{\mathrm{N}}+\mathrm{C}_{\mathrm{U}}$ ) and the starting (initial) measured $\beta-\mathrm{LG}$ concentration of the WPI fouling solution.

The temperature-dependent reaction rate constants $\left(\mathrm{k}_{\mathrm{unf}}\right.$ and $\left.\mathrm{k}_{\mathrm{agg}}\right)$ are derived from Equations [6] and [7] by using the kinetic parameters included in Table 2. Discretization was carried out with a time step equal

Table 3. Calculation of the unfolding degree of $\beta$-lactoglobulin $(\beta-\mathrm{LG} ; \alpha)$ on the basis of the formal kinetic parameters and according to Equation $[11]^{1}$

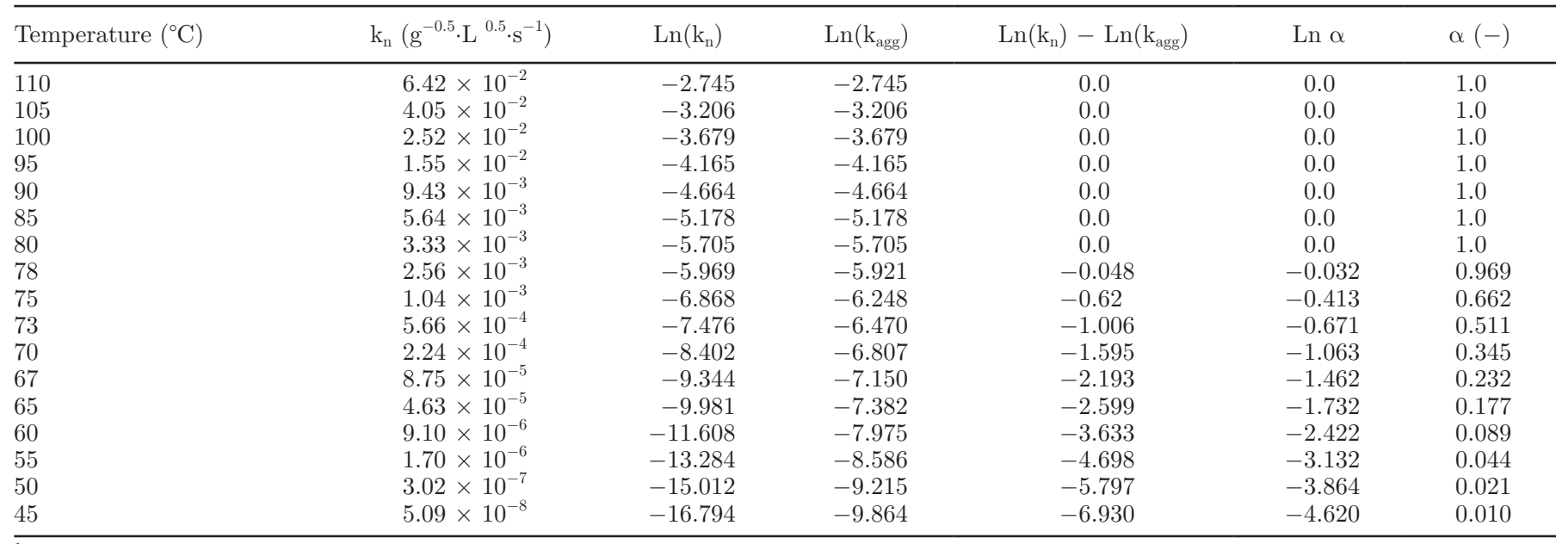

${ }^{1} \mathrm{k}_{\mathrm{n}}$ is the formal $\beta$-LG denaturation rate constant for a reaction order equal to $\mathrm{n}$, as defined by Equation [2]; $\mathrm{k}_{\mathrm{agg}}$ is the aggregation reaction rate constant; $\alpha$ is the unfolding degree of $\beta-\mathrm{LG}$. 
to $0.01 \mathrm{~s}$, which resulted in sufficiently good accuracy of calculated data. The simplifying assumptions used in the calculation of the concentrations $\mathrm{C}_{\mathrm{N}}, \mathrm{C}_{\mathrm{U}}$, and $\mathrm{C}_{\mathrm{A}}$ are the following: (1) the flow in the whey protein treating PHE is considered as a one-dimensional plug flow model, (2) the temperature profile into the bulk fluid is linear in each channel c of the PHE (i.e., local temperature gradients within the thermal boundary layer are not taken into account), and (3) the loss of the unfolded $\beta$-LG protein along the PHE involved in the deposition process is not considered.

\section{Statistical Analysis}

Statistical analyses of deposit mass were performed using SigmaStat 3.1 and SigmaPlot 10.0 software (Systat Software Inc., Point Richmond, CA). The level of significance was $P$-value $<0.05$.

\section{RESULTS AND DISCUSSION}

\section{Influence of the Temperature Profiles on Dry Deposit Masses}

Figures 6a, 6b, 6c, 6d, and 6e present the dry deposit masses measured in each channel at the end of the experiments for 5 representative fouling runs (corresponding to experiments $\# 1, \# 2, \# 3, \# 6$, and \#15, respectively) together with the concentration profiles of the different $\beta$-LG species (N, U, A) determined numerically along the PHE. For sake of clarity, scales concerning some protein species concentrations have been divided by a shift factor and are indicated in the legend. As expected, the distribution of dry masses of deposit within the PHE channels was influenced significantly by the temperature profile. It can be observed that the more severe the thermal treatment, the more the distribution of dry masses of deposit is located in the first channels of the PHE. For low temperature treatments, dry deposit masses are more important close to the PHE outlet.

As for the dry deposit masses, the apparition and disappearance of protein species (N, U, A) appear to be significantly affected by the temperature profile. In general, species $U$ appears earlier and at a higher concentration in the PHE than species A. This confirms that unfolding and aggregation reactions have a predominant area depending on the temperature range. Species N disappears progressively along the PHE but at different residence times depending on the temperature profile imposed. Figures 6 a to $6 \mathrm{~d}$ show evidences of the nonlinearity of population species balance: concentration $\mathrm{C}_{\mathrm{A}}$ is not simply complementary to concentration $\mathrm{C}_{\mathrm{N}}$.
Concerning the species concentration, it could be observed that

(1) when relatively low temperature $\left(45^{\circ} \mathrm{C}<\mathrm{T}_{\text {ip }}<\right.$ $70^{\circ} \mathrm{C}$ ) compared with the denaturation temperature of $\beta$-LG (circa $74-76^{\circ} \mathrm{C}$, Guérin et al., 2007) is set at the PHE inlet, the concentration of $\mathrm{N}$ $\left(\mathrm{C}_{\mathrm{N}}\right)$ is close to its initial value (i.e., $\approx 53.3 \mathrm{~g} \cdot \mathrm{L}^{-1}$ ) and $\mathrm{U}$ remains at a low concentration level $\left(\mathrm{C}_{\mathrm{U}}\right.$ $\left.<8.9 \mathrm{~g} \cdot \mathrm{L}^{-1}\right)$, whereas $\mathrm{A}$ is either not detected or is at a concentration level that is considerably lower than $\mathrm{C}_{\mathrm{U}}\left(\mathrm{C}_{\mathrm{A}}<2.7 \mathrm{~g} \cdot \mathrm{L}^{-1}\right.$; Figures $6 \mathrm{a}, 6 \mathrm{c}$, and $6 \mathrm{e})$.

(2) A significant concentration of A (different of zero) occurs only for run \#6 (Figure 6d) for which the inlet PHE temperature was the highest $\left(\mathrm{T}_{\mathrm{ip}}=70^{\circ} \mathrm{C}\right)$.

(3) The concentration profile of the unfolded $\beta$-LG $\left(\mathrm{C}_{\mathrm{U}}\right)$ is characterized by (i) an initial increase depending on the product temperature, (ii) a maximum value appearing earlier in the PHE if the product temperature is high, and (iii) following this maximum, a decrease at the expense of $\mathrm{C}_{\mathrm{A}}$ up to the PHE outlet.

(4) The concentration of the aggregated $\beta-L G\left(C_{A}\right)$ increased strongly from the channel for which $\mathrm{C}_{\mathrm{U}}$ reached its maximum value (Figures 6a and 6d), then increased more slowly up to the PHE outlet. The concentration profile of the aggregated $\beta$-LG $\left(\mathrm{C}_{\mathrm{A}}\right)$ did not exhibit a maximum contrary to what observed for $\mathrm{C}_{\mathrm{U}}$.

The $\beta$-LG unfolding and aggregation process was thus markedly affected by the average temperature prevailing in the $\mathrm{PHE}$, which is in agreement with previous studies using the same WPI fouling solution (Petit et al., 2011, 2013). Indeed the aggregation level measured at the PHE outlet increased from 49.8 to $97.3 \%$ for a $\mathrm{T}_{\text {op }}$ value ranging from 70 to $95^{\circ} \mathrm{C}$, respectively. This observation is due to the significant enhancement of the $\beta$-LG unfolding and aggregation kinetics with temperature as described by the Arrhenius equation.

The simulated concentration profiles presented in Figure 6 are consistent with the distribution of $\mathrm{C}_{\mathrm{N}}, \mathrm{C}_{\mathrm{U}}$, and $\mathrm{C}_{\mathrm{A}}$ calculated using computational fluid dynamics (CFD) in the modeling of both a single-channel PHE during pasteurization of milk (De Bonis and Ruocco, 2009). These concentration profiles are also in good agreement with the typical concentration-time curves reported by de Jong et al. (1992), who considered, however, that the heat-induced denaturation of $\beta-\mathrm{LG}$ could be described as a consecutive reaction of unfolding and aggregation $(\mathrm{N} \rightarrow \mathrm{U} \rightarrow \mathrm{A})$, which differs from the set 
of reversible consecutive reactions used in this study (see Figure 5).

\section{Bulk $\beta$-LG Species Concentrations and Dry Deposit Mass Distribution}

To make the connection between the role of the bulk protein unfolding and aggregation process and the mechanism of deposit formation, the experimental distribution of the dry deposit mass along the PHE channels $c$ (noted $\mathrm{m}_{\text {dep.c }}$ ) and the variation of the concentration of unfolded $\left(\mathrm{C}_{\mathrm{U}}\right)$ and aggregated $\left(\mathrm{C}_{\mathrm{A}}\right) \beta-\mathrm{LG}$ have been analyzed simultaneously.

From this analysis, it appears clearly that aggregates are not the precursor of deposit. Indeed, the appearance of $\beta$-LG aggregates is subsequent to fouling (Figures $6 \mathrm{a}, 6 \mathrm{c}$, and $6 \mathrm{e}$ ) and one can observe a decrease in the deposited mass when $\mathrm{C}_{\mathrm{A}}$ increases sharply for all runs. This confirms that aggregates are not major species involved in whey protein deposit formation. This investigation also illustrates unambiguously that the release of unfolded $\beta$-LG within the bulk fluid (and its nonconsumption in the form of $\beta$-LG aggregates) is a key phenomenon that controls the extent of protein fouling as well as its location inside the PHE.

This assumption is in agreement with previous results reported by Blanpain-Avet et al. (2012) through a Raman analysis of the first deposit layer located at the stainless steel-fouling layer interface; indeed BlanpainAvet et al. (2012) clearly demonstrated that protein species present in the first layer of the deposit have a secondary structure which differs significantly from that of the aggregates, $\beta$-LG aggregates being characterized by an irreversibly altered secondary structure.

This result is also in coherence with authors who have argued that favoring the formation of protein aggregates could be a way to reduce fouling (de Jong et al., 1992; Delplace et al., 1997; Van Asselt et al., 2005). It can also be seen that the experimental deposit mass continually increases up to the pass in the PHE where the aggregation rate increases significantly. The same observation was made by de Jong et al. (1993) in the case of the modeling of whole milk fouling in a PHE.

Figure 6 also indicates that, in the absence of species $A$, very little $U$ species into the bulk fluid is enough for the observation of a $\beta-L G$ deposit. This result is in agreement with the observation of Delplace and Leuliet (1995) who noted that very low quantities of denatured $\beta-\mathrm{LG}$ are required to observe an increase in the dry deposit mass.

As shown in Figure 6, the hypothesis that species U is the precursor of a whey protein fouling in the 70 to $95^{\circ} \mathrm{C}$ temperature range and that the aggregation reac- tion limits fouling, appears to be plausible because the fouling rate, derived from the measurement of deposit masses, decreases when the aggregate concentration increases.

This result is also in agreement with the work of Petit et al. (2013) who led a dimensional analysis to identify the dimensionless numbers governing the fouling and the aggregation formation when a WPI fouling solution (of the same chemical composition) is heated in a pilotscale PHE. Indeed these authors showed that the total dry masses of deposit collected in the PHE were essentially governed by the Arrhenius exponential factor of the $\beta$-LG unfolding reaction, that is $\exp \left[-\mathrm{E}_{\mathrm{a} \text {,unf }} /\left(\mathrm{R}_{\text {gas }}\right.\right.$. $\left.T_{\text {ip }}\right)$ ], which combines in a single dimensionless number the overwhelming influence of temperature and $\beta$-LG reactivity in regard to the unfolding. This is also in agreement with the statement of Bouvier et al. (2014) who underlined, using a two-dimensional CFD analysis and experimental fouling trials, that the unfolded $\beta$-LG is a precursor of the dry deposit at the heat transfer wall.

\section{Modeling the Distribution of the Dry Deposited Fouling Mass}

To consolidate the hypothesis of a direct contribution of the competitive reactions of unfolding and aggregation taking place in the bulk fluid to the deposit formation rate within the $\mathrm{PHE}$, an attempt has been made to model the dry deposit mass per channel through the ratio $\mathrm{R}$ between the unfolding reaction rate constant (noted $\mathrm{k}_{\mathrm{unf}}$ ) and the aggregation reaction rate constant (noted $\mathrm{k}_{\mathrm{agg}}$ ).

For each channel of the PHE, the ratio $\mathrm{R}=\mathrm{k}_{\mathrm{unf}} /$ $\mathrm{k}_{\mathrm{agg}}$ was calculated at the arithmetic mean bulk temperature of the channel, $T_{c, b}$ (i.e., corresponding to the approximated bulk temperature at the middle point of the channel noted c, by assuming a linear temperature profile along the PHE):

$$
\mathrm{T}_{\mathrm{c}, \mathrm{b}}=\frac{\mathrm{T}_{\mathrm{c}, \mathrm{in}}+\mathrm{T}_{\mathrm{c}, \mathrm{out}}}{2},
$$

where $T_{c, \text { in }}$ and $T_{c, \text { out }}$ are the temperatures at the inlet and outlet of the channel c of the PHE, respectively.

$\mathrm{R}$ is a dimensionless ratio indicating the degree of completion of the heat-induced denaturation reaction, which is of course strongly affected by the temperature level and by the physico-chemical environment of the fouling solution (i.e., protein concentration and composition, mineral content affecting the kinetic denaturation rate constant). When we transform into logarithmic scale, it is seen that the ratio $\mathrm{R}$ represents the differ- 

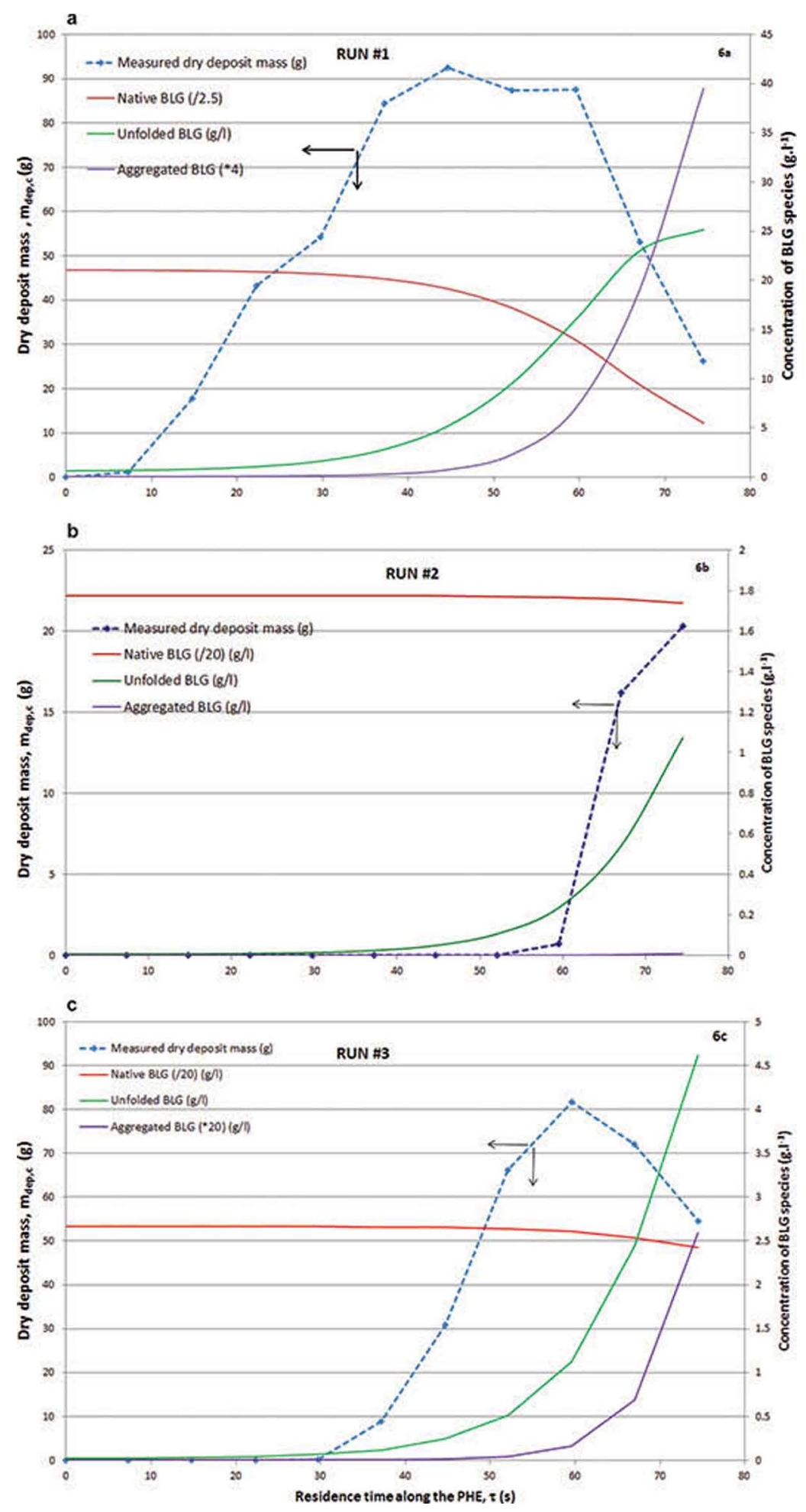

Figure 6. Typical and representative variation with the residence time within the plate heat exchanger (PHE; $\tau)$ of both the predicted concentration profile of the various $\beta$-lactoglobulin $(\beta-\mathrm{LG})$ species [native $(\mathrm{N})$, unfolded $(\mathrm{U})$, and aggregated $(\mathrm{A})$ ] and the experimental dry deposit mass in the various channels $\left(\mathrm{m}_{\text {dep,c }}\right)$ for various operating conditions (i.e., experiments $\# 1, \# 2$, \#3, \#6, and \#15). Panel a corresponds to run $\# 1\left(\mathrm{~T}_{\mathrm{op}}=85.1^{\circ} \mathrm{C}, \mathrm{T}_{\mathrm{oh}}=62.7^{\circ} \mathrm{C}, \tau=74.6 \mathrm{~s}\right.$, and $\left.\varepsilon=90.3 \%\right)$; panel b corresponds to run $\# 2\left(\mathrm{~T}_{\mathrm{op}}=70^{\circ} \mathrm{C}, \mathrm{T}_{\mathrm{oh}}=47.7^{\circ} \mathrm{C}, \tau=74.6 \mathrm{~s}\right.$, and $\varepsilon=$ $89.9 \%)$; panel c corresponds to run $\# 3\left(\mathrm{~T}_{\mathrm{op}}=75^{\circ} \mathrm{C}, \mathrm{T}_{\mathrm{oh}}=52.7^{\circ} \mathrm{C}, \tau=74.6 \mathrm{~s}\right.$, and $\left.\varepsilon=89.9 \%\right)$; panel d corresponds to run \#6 $\left(\mathrm{T}_{\mathrm{op}}=95^{\circ} \mathrm{C}\right.$, $\mathrm{T}_{\mathrm{oh}}=72.7^{\circ} \mathrm{C}, \tau=74.6 \mathrm{~s}$, and $\left.\varepsilon=90.3 \%\right)$; and panel e corresponds to run $\# 15\left(\mathrm{~T}_{\mathrm{op}}=85.1^{\circ} \mathrm{C}, \mathrm{T}_{\mathrm{oh}}=60.8^{\circ} \mathrm{C}, \tau=37.3 \mathrm{~s}\right.$, and $\left.\varepsilon=65.2 \%\right)$. $\mathrm{T}_{\mathrm{op}}$ is the WPI fouling solution temperature at the PHE outlet $\left({ }^{\circ} \mathrm{C}\right) ; \mathrm{T}_{\text {oh }}$ is the hot water temperature at the PHE outlet $\left({ }^{\circ} \mathrm{C}\right) ; \varepsilon$ is the heat exchange efficiency on the product side, dimensionless. Color version available online. 

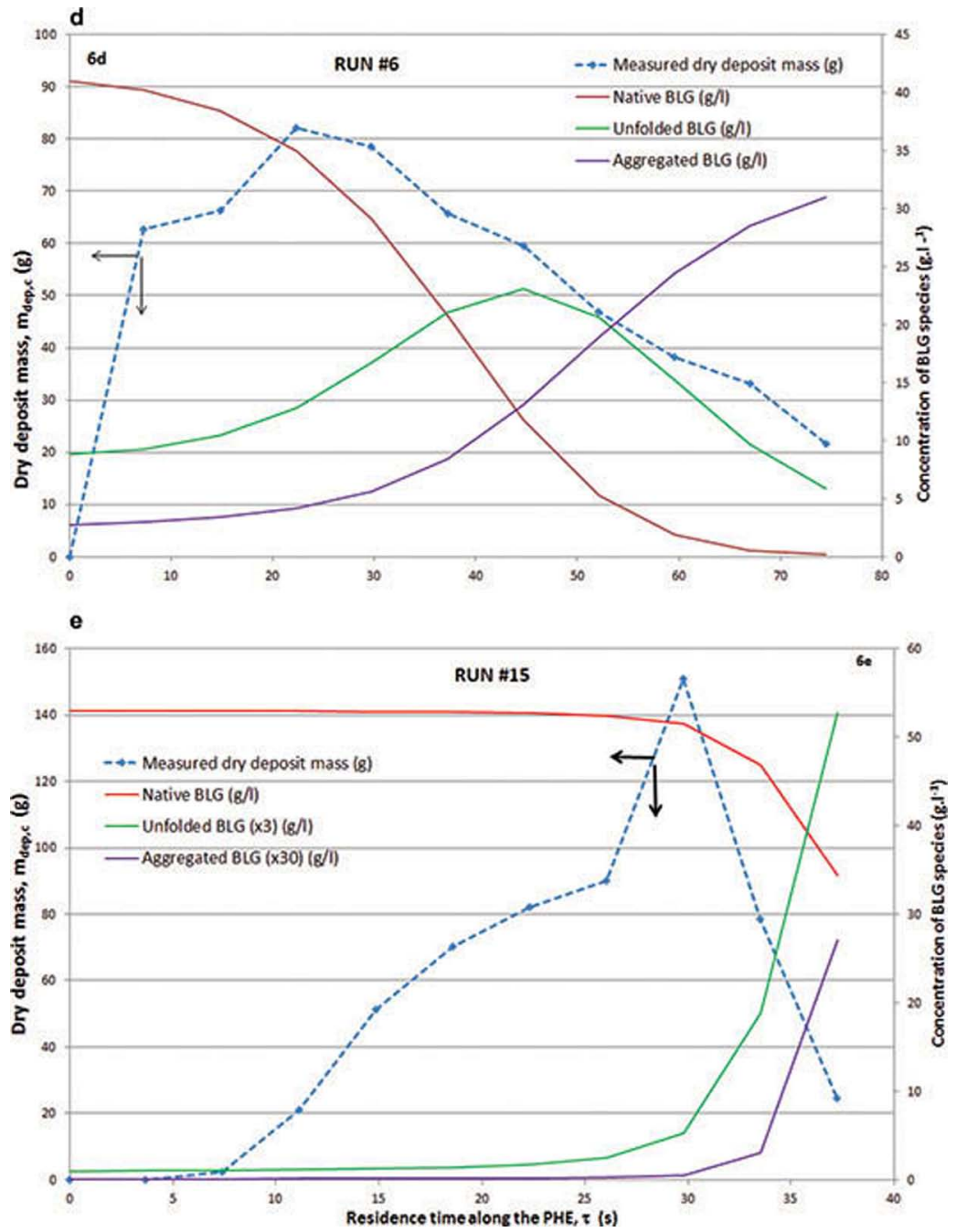

Figure 6 (Continued). Typical and representative variation with the residence time within the plate heat exchanger (PHE; $\tau)$ of both the predicted concentration profile of the various $\beta$-lactoglobulin $(\beta-\mathrm{LG})$ species [native $(\mathrm{N})$, unfolded (U), and aggregated (A)] and the experimental dry deposit mass in the various channels $\left(\mathrm{m}_{\mathrm{den}}\right)$ for various operating conditions (i.e., experiments \#1, \#2, \#3, \#6, and \#15). Panel a corresponds to run $\# 1\left(\mathrm{~T}_{\mathrm{op}}=85.1^{\circ} \mathrm{C}, \mathrm{T}_{\mathrm{oh}}=62.7^{\circ} \mathrm{C}, \tau=74.6 \mathrm{~s}\right.$, and $\left.\varepsilon=90.3 \%\right)$; panel b corresponds to run $\# 2\left(\mathrm{~T}_{\mathrm{op}}=70^{\circ} \mathrm{C}, \mathrm{T}_{\mathrm{oh}}=47.7^{\circ} \mathrm{C}, \tau=\right.$ $74.6 \mathrm{~s}$, and $\varepsilon=89.9 \%)$; panel c corresponds to run $\# 3\left(\mathrm{~T}_{\mathrm{op}}=75^{\circ} \mathrm{C}, \mathrm{T}_{\mathrm{oh}}=52.7^{\circ} \mathrm{C}, \tau=74.6 \mathrm{~s}\right.$, and $\left.\varepsilon=89.9 \%\right)$; panel d corresponds to run \#6 $\left(\mathrm{T}_{\mathrm{op}}=95^{\circ} \mathrm{C}, \mathrm{T}_{\mathrm{oh}}=72.7^{\circ} \mathrm{C}, \tau=74.6 \mathrm{~s}\right.$, and $\left.\varepsilon=90.3 \%\right)$; and panel e corresponds to run $\# 15\left(\mathrm{~T}_{\mathrm{op}}=85.1^{\circ} \mathrm{C}, \mathrm{T}_{\mathrm{oh}}=60.8^{\circ} \mathrm{C}, \tau=37.3 \mathrm{~s}\right.$, and $\varepsilon=$ $65.2 \%) . \mathrm{T}_{\mathrm{op}}$ is the WPI fouling solution temperature at the PHE outlet $\left({ }^{\circ} \mathrm{C}\right) ; \mathrm{T}_{\mathrm{oh}}$ is the hot water temperature at the PHE outlet $\left({ }^{\circ} \mathrm{C}\right) ; \varepsilon$ is the heat exchange efficiency on the product side, dimensionless. Color version available online.

ence in logarithm between the unfolding rate constant and the aggregation one [i.e., $\left.\ln \left(\mathrm{k}_{\mathrm{unf}}\right)-\ln \left(\mathrm{k}_{\mathrm{agg}}\right)\right]$. $\mathrm{R}$ is thus equal to 1 at the critical temperature $\left(\mathrm{T}_{\text {critical }}\right)$ of the sharp edge on the Arrhenius plot (Figure 4).

Figure 7 represents the variation of the measured dry deposit mass per channel (noted $\mathrm{m}_{\text {dep,c }}$ ) with the ratio $\mathrm{R}$ for all the PHE temperature profiles imposed. For sake of clarity, fouling trials are classified in different symbols, indicating the independent process parameters that have varied $\left(\mathrm{T}_{\mathrm{op}}\right.$ : triangle, $\Delta \mathrm{T}_{\mathrm{p}}$ : square, $\tau$ : circle, and $\varepsilon$ : diamond) and lead to a different temperature profile.
Analysis of Figure 7 shows that the $m_{\text {dep,c }}$ versus $R$ representation is capable reasonably well of gathering all the experimental dry deposit mass per channel data onto a unique fitting master curve, independent of the temperature profile imposed. For all fouling runs, $m_{\text {dep }, \mathrm{c}}$ versus $\mathrm{R}$ data could be described by the following 4-parameter nonlinear function:

$$
\mathrm{m}_{\mathrm{dep}, \mathrm{c}}=\mathrm{a}+\mathrm{b} \cdot \exp \left[-0.5 \cdot\left(\frac{\ln (\mathrm{R} / \mathrm{c})}{\mathrm{d}}\right)^{2}\right],
$$




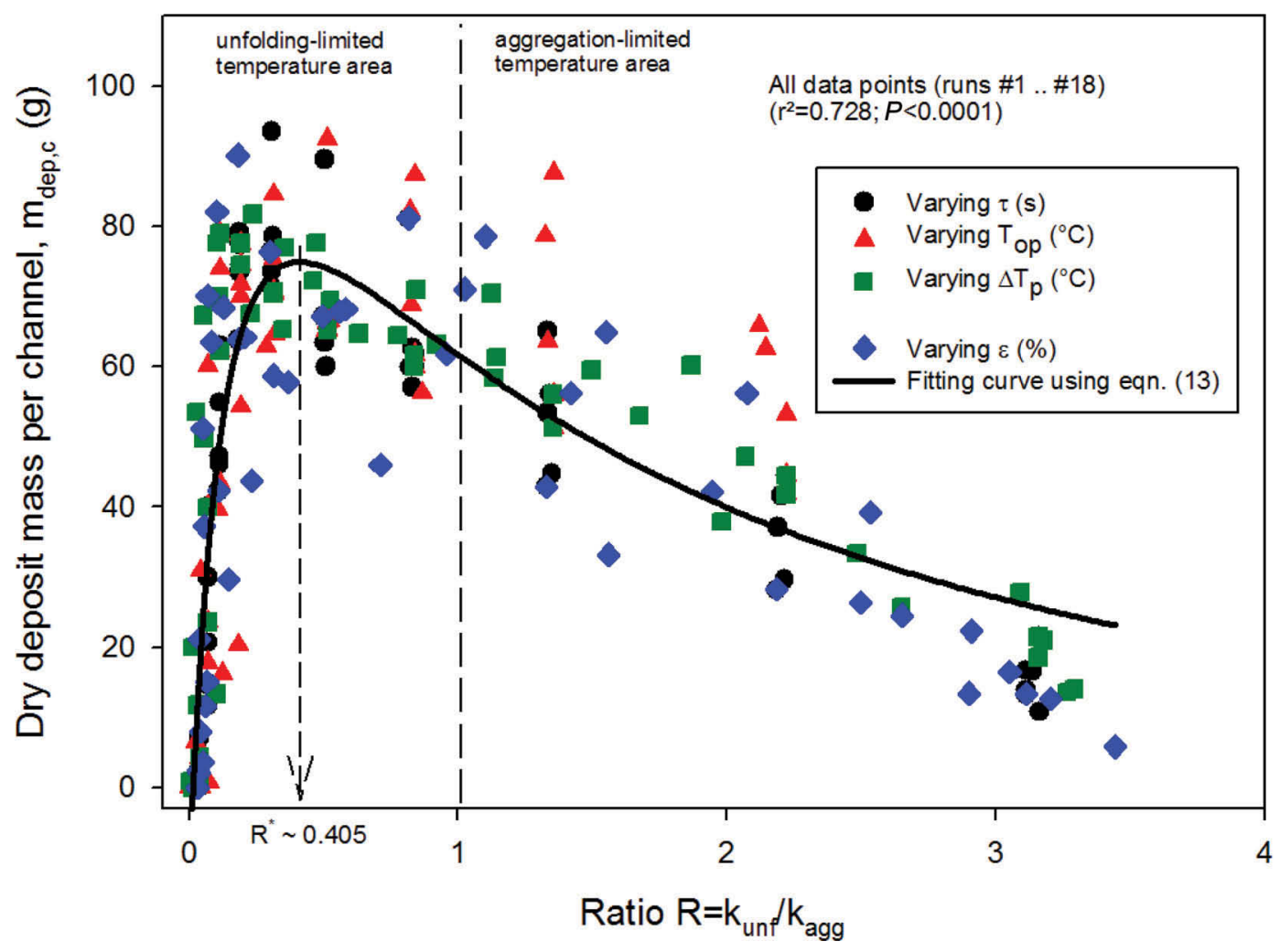

Figure 7. Variation of the dry deposit mass in the various channels of the plate heat exchanger (PHE; $\mathrm{m}_{\text {dep,c }}$ ) with the ratio $\mathrm{R}$ derived at $\mathrm{T}_{c, \mathrm{~b}}$ using Equations [6], [7], and [12], for all experiments (from run \#1 to run \#18). $\mathrm{T}_{c, \mathrm{~b}}$ is the arithmetic mean of $\mathrm{T}_{c, \text { in }}$ and $\mathrm{T}_{c, \text { out }}$, as defined by Equation [12], corresponding to the approximated bulk temperature at the middle point of a channel c $\left({ }^{\circ} \mathrm{C}\right)$; $\mathrm{T}_{\mathrm{op}}$ is the whey protein isolate (WPI) fouling solution temperature at the PHE outlet $\left({ }^{\circ} \mathrm{C}\right) ; \Delta \mathrm{T}_{\mathrm{p}}$ is the WPI fouling solution temperature increase between the PHE inlet and outlet $\left(\mathrm{T}_{\mathrm{op}}-\mathrm{T}_{\mathrm{ip}} ;{ }^{\circ} \mathrm{C}\right)$, where $\mathrm{T}_{\mathrm{ip}}$ is the WPI fouling solution temperature at the PHE inlet; $\varepsilon$ is the heat exchange efficiency on the product side, dimensionless; $k_{\text {agg }}$ is the aggregation reaction rate constant $\left(\mathrm{kg}^{1-\mathrm{n}} \cdot \mathrm{m}^{-3(1-\mathrm{n})} \cdot \mathrm{s}^{-1}\right) ; \mathrm{k}_{\mathrm{unf}}$ is the unfolding reaction rate constant $\left(\mathrm{kg}^{1-n} \cdot \mathrm{m}^{-3(1-\mathrm{n})} \cdot \mathrm{s}^{-1}\right)$. The fitting curve of experimental data was derived from Equation [13]. Color version available online.

where $\mathrm{a}$ is the adjusted parameter in the nonlinear regression, $\mathrm{b}$ is the adjusted parameter in the nonlinear regression, $\mathrm{c}$ is the adjusted parameter in the nonlinear regression, and $\mathrm{d}$ is the adjusted parameter in the nonlinear regression. A reasonably good fit could be reached $\left(\mathrm{R}^{2}=0.728, P<0.0001\right)$. Raw residuals (i.e., $\mathrm{y}_{\mathrm{i}}-\hat{\mathrm{y}}_{\mathrm{i}}$, data not shown) were found to be quite well distributed around zero, indicating that no bias was introduced by the model.

This result representation clearly shows that chemical reactions on the bulk control the dry fouling mass distribution inside a PHE. This result also shows the importance of determining a priori the denaturation rate constants to predict the fouling mass distribution.

The $m_{\text {dep.c }}$ versus $R$ curves were characterized by different zones: (1) an initial sharp increase at values of $\mathrm{R}$ close to zero, followed by a maximum of the deposit mass at a certain value of $\mathrm{R}$ (noted $\mathrm{R}^{*}=\mathrm{k}_{\mathrm{unf}} / \mathrm{k}_{\mathrm{agg}}$ ), where $R^{*}$ is the value of the ratio $\mathrm{R}=\mathrm{k}_{\mathrm{unf}} / \mathrm{k}_{\mathrm{agg}}$ corresponding to the maximum of the fitted $\mathrm{m}_{\text {dep,c }}$ versus $\mathrm{R}$ curve (i.e., $\mathrm{R}^{*}=\mathrm{k}_{\mathrm{unf}} / \mathrm{k}_{\mathrm{agg}} *$ ), for which the dry deposit mass $m_{\text {dep c }}$ is the highest, dimensionless; and (2) then beyond $\mathrm{R}^{*}$ it is observed a gradual decrease in the deposit mass with increasing values of $R$.

It is noticed that the $R$ values at which fouling begins to form are very close to zero: $\mathrm{R}=0.0065,0.01,0.0305$, and 0.037 , respectively, for the different series $\Delta \mathrm{T}_{\mathrm{p}}, \mathrm{T}_{\mathrm{op}}$, $\varepsilon$, and $\tau$ (Table 4 ), that is, at $\mathrm{T}_{c, \mathrm{~b}} \ll \mathrm{T}_{\text {critical }}$ within the unfolding-limited temperature area; this confirms, as shown in Figure 6, that very little $\mathrm{U}$ species is required into the bulk fluid for $\beta-L G$ fouling to be deposited.

Interestingly, the maximum of the deposit mass derived from the fitting curve (beyond which $\mathrm{m}_{\mathrm{dep}, \mathrm{c}}$ decreases gradually, see Figure 7) takes place at an almost constant $\mathrm{R}^{*}$ value for the investigated operating conditions: $0.339<\mathrm{R}^{*}<0.659$ for the different series, corresponding to bulk temperatures (noted $\mathrm{T}^{*}$ ) ranging from 71.8 to $75.5^{\circ} \mathrm{C}$ (Table 4), that is, at a temperature inferior to $\mathrm{T}_{\text {critical }}$.

From the plot of the fitting curve of the $\mathrm{m}_{\text {dep,c }}$ versus $\mathrm{R}$ data points for all experiments (Figure 7), several 
Table 4. Values of the ratio $\mathrm{R}=\mathrm{k}_{\mathrm{unf}} / \mathrm{k}_{\mathrm{agg}}$ corresponding to the maximum of the fitted $\mathrm{m}_{\mathrm{dep}, \mathrm{c}}$ versus $\mathrm{R}$ curve (i.e., $\mathrm{R}^{*}=\mathrm{k}_{\mathrm{unf}} / \mathrm{k}_{\mathrm{agg}}{ }^{*}$ ) for which the deposit mass $\mathrm{m}_{\text {dep.c }}$ is the highest together with the corresponding bulk temperature $\left(\mathrm{T}^{*}\right)$, and values of the ratio $\mathrm{k}_{\mathrm{unf}} / \mathrm{k}_{\mathrm{agg}}$ at which fouling begins to build up (i.e., when $\left.\mathrm{m}_{\mathrm{dep}, \mathrm{c}} \geq 0.1\right)^{1}$

\begin{tabular}{|c|c|c|c|}
\hline Type of experiment & $\mathrm{R}^{*}=\mathrm{k}_{\mathrm{unf}} / \mathrm{k}_{\mathrm{agg}} *$ & $\mathrm{~T}^{*}\left({ }^{\circ} \mathrm{C}\right)$ & $\begin{array}{c}\mathrm{R} \text { at which fouling } \\
\text { begins to build up } \\
\text { [i.e., when } \mathrm{m}_{\mathrm{dep}, \mathrm{c}} \geq 0.1 \mathrm{~g}\end{array}$ \\
\hline$\overline{\text { Varying } \tau(\mathrm{s})}$ & 0.391 & 72.6 & 0.037 \\
\hline Varying $\mathrm{T}_{\mathrm{op}}\left({ }^{\circ} \mathrm{C}\right)$ & 0.659 & 75.5 & 0.01 \\
\hline Varying $\varepsilon(\%)$ & 0.362 & 72.1 & 0.0305 \\
\hline Varying $\Delta \mathrm{T}_{\mathrm{p}}\left({ }^{\circ} \mathrm{C}\right)$ & 0.339 & 71.8 & 0.0065 \\
\hline $\begin{array}{l}\text { All data points } \\
\text { (runs } \# 1 \ldots \# 18 \text { ) }\end{array}$ & 0.405 & 72.8 & 0.0145 \\
\hline
\end{tabular}

${ }^{1} \mathrm{k}_{\text {unf }}$ is the unfolding reaction rate constant $\left(\mathrm{kg}^{1-\mathrm{n}} \cdot \mathrm{m}^{-3(1-\mathrm{n})} \cdot \mathrm{s}^{-1}\right) ; \mathrm{k}_{\mathrm{agg}}$ is the aggregation reaction rate constant $\left(\mathrm{kg}^{1-\mathrm{n}} \cdot \mathrm{m}^{-3(1-\mathrm{n})} \cdot \mathrm{s}^{-1}\right) ; \mathrm{m}_{\text {dep.c }}$ measured dry fouling deposit mass in a channel $\mathrm{c}$ along the plate heat exchanger (PHE; $\mathrm{kg}$ ); $\tau$ is the mean residence time of the whey protein isolate (WPI) fouling solution in the PHE (s); $\mathrm{T}_{\mathrm{op}}$ is the WPI fouling solution temperature at the PHE outlet $\left({ }^{\circ} \mathrm{C}\right) ; \varepsilon$ is the heat exchange efficiency on the product side, dimensionless; $\Delta \mathrm{T}_{\mathrm{p}}$ is the WPI fouling solution temperature increase between the PHE inlet and outlet $\left(\mathrm{T}_{\mathrm{op}}-\mathrm{T}_{\mathrm{ip}} ;{ }^{\circ} \mathrm{C}\right)$, where $\mathrm{T}_{\mathrm{ip}}$ is the WPI fouling solution temperature at the PHE inlet.

valuable insights into the $\beta$-LG fouling mechanisms can be drawn.

Fouling first builds up and deposit mass increases sharply in the unfolding-limited temperature area up to a critical value of the ratio $R$ (i.e., $R^{*} \approx 0.405$ ), where the deposit mass is the highest, as shown in Figure 7. At temperatures below $78^{\circ} \mathrm{C}\left(\mathrm{T}_{\text {critical }}\right)$ corresponding to the unfolding-limited temperature area, the unfolding degree is insufficient for the irreversible aggregation reaction to be predominant: the probability of a collision between 2 unfolded $\beta$-LG molecules is low under these conditions so that the fouling growth until the maximum of deposited fouling mass is primarily caused by the deposition of unfolded $\beta$-LG.

Beyond $\mathrm{R}^{*} \approx 0.405$ at an increasing temperature along the PHE, it is observed in Figure 7 an important and significant decrease in the deposit mass up to a $R$ value close to about 1 beyond which the rate of fouling mass decrease reduces progressively within the aggregation-limited temperature area. In the aggregation-limited area, $\beta$-LG unfolding is completed so that only the unfolded $\beta$-LG molecules exist in the solution (i.e., $\alpha=1$, Figure 4 ).

This decrease in fouling may be interpreted and explained by the consumption of the unfolded $\beta-\mathrm{LG}$ molecules for the formation in the bulk fluid of $\beta$-LG aggregates: an increase in the collision probability between unfolded $\beta$-LG molecules will promote aggregate formation rather than deposit layer formation as pointed out by Delplace et al. (1997).

From the data analysis in the sections above, the predominant role of the unfolded $\beta$-LG in the rise of fouling has been shown. The representation adopted (i.e., $\mathrm{m}_{\text {dep,c }}$ versus $\mathrm{R}$ ) gives a concise and unprecedented view of the competitive reactions (unfolding and aggregation) governing the growth of fouling for a WPI solution. This curve (Figure 7) was validated when $T_{\text {wall }}$ values are very close to $T_{b}$ values along the PHE (see Figure 3a). This curve made it possible to explain the decrease in the deposit mass which occurs when $\mathrm{C}_{\mathrm{A}}$ exponentially increases along the PHE.

Interestingly, it should also be stated that this approach has been successfully used by Khaldi et al. (2015b,c) for another PHE arrangement and a substantially different derivative milk-based product [see Figure 8 extracted and adapted from Khaldi et al. (2015b,c)]. Indeed the PHE set-up consisted of 5 passes (one channel per pass) for Khaldi et al. (2015b,c) instead of 10 passes (one channel per pass) in this study. In our case, the fouling solution is a $\beta$-LG concentrate composed almost exclusively of $\beta$-LG ( 89 wt \% in $\beta$-LG plus less than $0.01 \mathrm{wt} \%$ of $\alpha$-LA) with $264 \mathrm{mg} \cdot \mathrm{L}^{-1}$ of ionic calcium. On the other hand, for Khaldi et al. (2015b,c), the product was a 1 wt \% reconstituted WPI solution (Promilk 852 FB1 from IDI SAS, Arras, France) composed of a whey protein mixture (66 wt $\% \beta$-LG plus 13 wt $\% \alpha$-LA) containing $100 \mathrm{mg} \cdot \mathrm{L}^{-1}$ of ionic calcium [more details can be found in Khaldi et al. $(2015 \mathrm{~b}, \mathrm{c})]$. In the same way, the fouling mass per channel was reasonably well correlated with the ratio $\mathrm{R}$ as shown by Figure 8, and whatever the temperature profile, a master fitting curve could be determined (Khaldi et al., 2015b,c); the shape of the fitting curve is different because the kinetic denaturation parameters $\left(\mathrm{k}_{0, \mathrm{unf}}, \mathrm{k}_{0, \mathrm{agg}}, \mathrm{E}_{\mathrm{a}, \mathrm{unf}}, \mathrm{E}_{\mathrm{a}, \mathrm{agg}}\right)$ are not the same.

These consolidated results show (1) the robustness of the reaction engineering approach used here to the analysis of fouling, and (2) that the identification of the heat-induced denaturation kinetics of $\beta$-LG by means of laboratory-scale experiments (i.e., in static conditions in the absence of fluid flow) is a prerequisite for the control of a whey protein fouling. Additionally, 


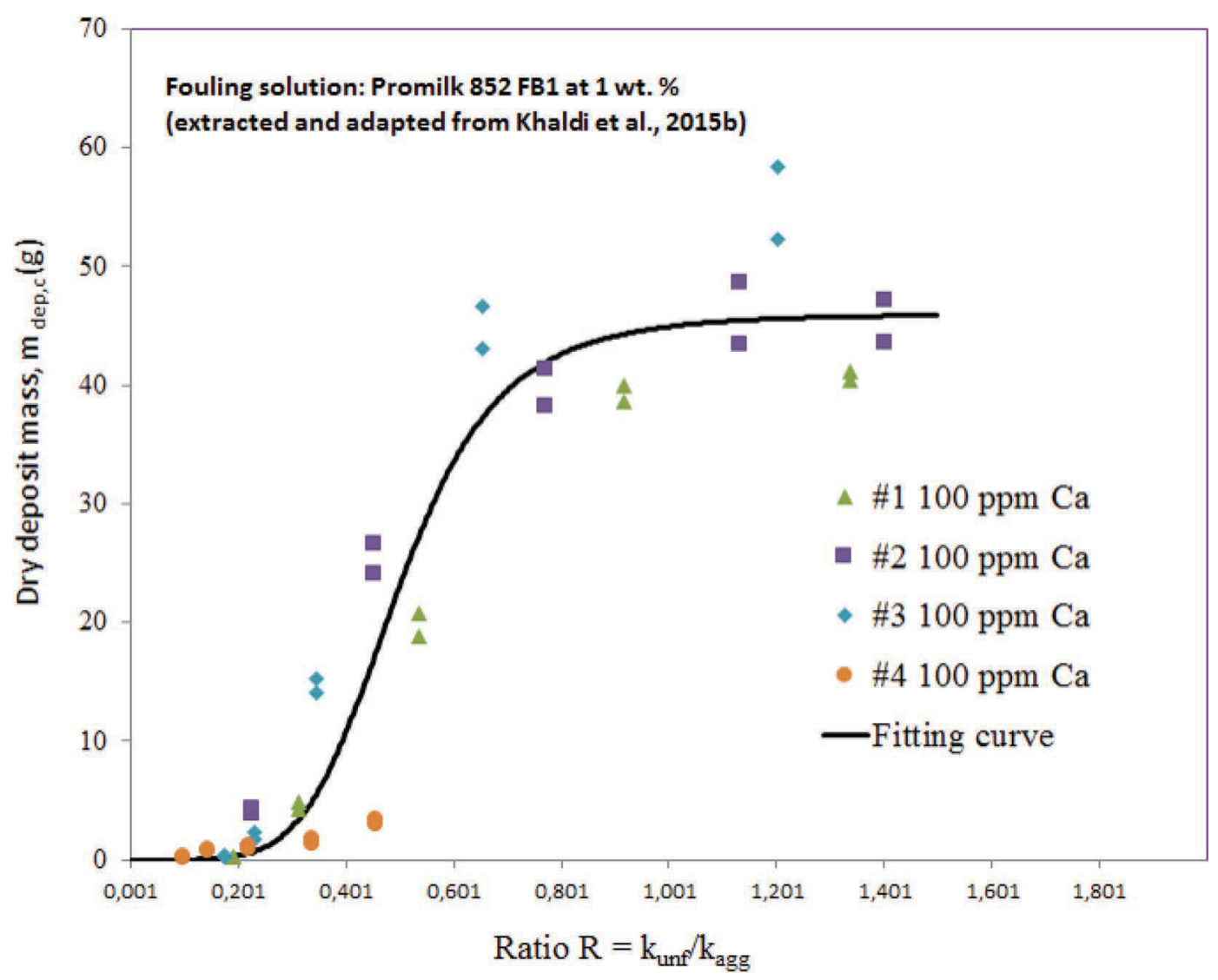

Figure 8. Variation of the dry deposit mass in the different channels of a corrugated plate heat exchanger (PHE) with the ratio R for a whey protein isolate (WPI) fouling solution composed of Promilk 852 FB1 (IDI SAS, Arras, France) at a concentration of 1 wt \% with a calcium content equal to $100 \mathrm{mg} \cdot \mathrm{L}^{-1}$ [extracted and adapted from Khaldi et al. $\left.(2015 \mathrm{~b}, \mathrm{c})\right] \cdot \mathrm{k}_{\mathrm{agg}}$ is the aggregation reaction rate constant $\left(\mathrm{kg}^{1-\mathrm{n}} \cdot \mathrm{m}^{-3(1-\mathrm{n})} \cdot \mathrm{s}^{-1}\right)$; $\mathrm{k}_{\mathrm{unf}}$ is the unfolding reaction rate constant $\left(\mathrm{kg}^{1-\mathrm{n}} \cdot \mathrm{m}^{-3(1-\mathrm{n})} \cdot \mathrm{s}^{-1}\right)$. Color version available online.

as our reaction engineering approach to the analysis of fouling was found to be applicable and appropriate for another PHE geometry (see Figure 8), this gives some confidence that our predictive model represented in Figure 7 is likely to be broadly applicable and likely not to be specific to the particular set-up (geometry) investigated.

Also, it would be interesting, through further experiments using very different types of heat exchanger, to see to what extent the predictive model is specific to the PHE type and geometry used, as the ratio $\mathrm{R}$ is certainly closely related to the flow and heat characteristics of the PHE (characteristics comprise the mixing intensity, residence time distribution, global heat transfer coefficient, and so forth). Further work is ongoing to determine to what extent the reaction engineering approach to the analysis of fouling developed in this study depends upon the geometry and arrangement of the PHE, and whether it can also be applied on various plate-type heat exchangers (e.g., plate-fin heat exchangers).

\section{CONCLUSIONS}

The comparison between the $\beta$-LG concentration profiles and the $\beta$-LG fouling deposit distribution along the PHE allowed us to put forward several important fouling mechanisms: (1) there is a decrease in the deposited mass when the aggregation process prevails, well before that $\mathrm{C}_{\mathrm{U}}$ decreases, $(2)$ very little $\mathrm{U}$ species into the bulk fluid is required for $\beta$-LG to be deposited onto the plates of the heat exchanger, and (3) the dry deposit mass distribution depends pretty much on a single parameter, the ratio between the unfolding rate constant and the aggregation rate constant (noted $\mathrm{R}$ ). The analysis of the database of the experimental runs clearly shows that the mass of dry deposit on each pass of the PHE is fairly well correlated with $\mathrm{R}$ and that this parameter alone is able to predict the location of the fouling deposit. Results definitely assigned the unfolded $\beta-\mathrm{LG}$ (or $\beta$-LG in the molten globule state) as the precursor species of fouling. Therefore, the type of reaction (i.e., unfolding versus aggregation) is very 
unlikely to be changed between the bulk fluid and the plate wall surface, which validates the appropriateness of the calculated concentration profiles (i.e., $\beta$-LG species N, U, and A) presented in Figures 6a to 6e. This study suggests that bulk processes are important in whey protein fouling in the 45 to $95^{\circ} \mathrm{C}$ range and that the prevalence of the concentration of $\beta-\mathrm{LG}$ aggregates limits fouling. It also appears that knowledge of the appropriate kinetic constants (for the unfolding and aggregation mechanism) is of great importance as the concentration evolution of the different $\beta$-LG species $(\mathrm{N}, \mathrm{U}$, and $\mathrm{A}$ ) within a PHE depends strongly on kinetic constants (especially the activation energy). Moreover, the distribution of protein species is strongly related to the distribution of the dry fouling masses.

\section{ACKNOWLEDGMENTS}

This work was carried out within the framework of an ALIBIOTECH (Agroalimentaire et Biotechno, Nord Pas-de-Calais region) program, which joined nonelucidated scientific issues of the research project (titled Phospho-fouling) led inside the INRA-CEPIA (Caractérisation et Elaboration des Produits issus de l'Agriculture) department (Action Incitative Conjointe). The authors also thank the Haut de France region and FEDER (Fonds européen de développement régional) for their financial support.

\section{REFERENCES}

Akkerman, M., V. M. Rauh, M. Christensen, L. B. Johansen, M. Hammershoj, and L. B. Larsen. 2016. Effect of heating strategies on whey protein denaturation-Revisited by liquid chromatography quadrupole time-of-flight mass spectroscopy. J. Dairy Sci. 99:152166.

Bansal, B., and X. D. Chen. 2006. A critical review of milk fouling in heat exchangers. Comprehensive Reviews in Food Science and Food Safety. 5:27-33.

Belmar-Beiny, M. T., and P. J. Fryer. 1992. Bulk and surface effects on the initial stages of whey fouling. Trans. IChemE 70:193-198.

Blanpain-Avet, P., A. Hédoux, Y. Guinet, L. Paccou, J. Petit, T. Six, and G. Delaplace. 2012. Analysis by Raman spectroscopy of the conformational structure of whey proteins constituting fouling deposits during the processing in a heat exchanger. J. Food Eng. 110:86-94.

Bouvier, L., A. Moreau, G. Ronse, T. Six, J. Petit, and G. Delaplace. 2014. A CFD model as a tool to simulate $\beta$-lactoglobulin heatinduced denaturation and aggregation in a plate heat exchanger. J. Food Eng. 136:56-63.

Boxler, C., W. Augustin, and S. Scholl. 2014. Influence of surface modification on the composition of a calcium phosphate-rich whey protein deposit in a plate heat exchanger. Dairy Sci. Technol. 94:17-31.

Burton, H. 1968. Deposit of whole milk in treatment plants-A review and discussion. J. Dairy Res. 34:317-330.

Changani, S. D., M. T. Belmar-Beiny, and P. J. Fryer. 1997. Engineering and chemical factors associated with fouling and cleaning in milk processing. Exp. Therm. Fluid Sci. 14:392-406.
Collier, N., D. Callens, P. Campistron, B. Nongaillard, M. Jimenez, G. Alogaili, P. Debreyne, and G. Delaplace. 2015. Ultrasonic adhesion measurement of whey protein fouling. Heat Transf. Eng. 36:1-9.

Dannenberg, F., and H. G. Kessler. 1986. Reaction kinetics of the denaturation of whey proteins. Pages 335-346 in Food Engineering and Process Applications. Vol. 1: Transport Phenomena. M. Le Maguer and P. Jelen, ed. Elsevier Applied Science, Amsterdam, the Netherlands.

De Bonis, M. V., and G. Ruocco. 2009. Conjugate fluid flow and kinetics modeling for heat exchanger fouling simulation. Int. J. Therm. Sci. 48:2006-2012.

de Jong, P. 1997. Impact and control of fouling in milk processing. Trends Food Sci. Technol. 8:401-405.

de Jong, P., S. Bouman, and H. J. Van Der Linden. 1992. Fouling of heat treatment equipment in relation to denaturation of $\beta$-lactoglobulin. J. Soc. Dairy Technol. 45:3-8.

de Jong, P., M. C. te Giffel, H. Straatsma, and M. M. M. Vissers. 2002. Reduction of fouling and contamination by predictive kinetic models. Int. Dairy J. 12:285-292.

de Jong, P., R. Waalewijn, and H. J. L. J. Van Der Linden. 1993. Validity of a kinetic fouling model for heat-treatment of whole milk. Lait 73:293-302.

De Wit, J. N. 2009. Thermal behaviour of bovine $\beta$-lactoglobulin at temperatures up to $150^{\circ} \mathrm{C}$. A review. Trends Food Sci. Technol. 20:27-34.

Delplace, F., and J.-C. Leuliet. 1995. Modelling fouling of a plate heat exchanger with different flow arrangements by whey protein solutions. Trans. IChemE 73:112-120.

Delplace, F., J.-C. Leuliet, and D. Levieux. 1997. A reaction engineering approach to the analysis of fouling by whey proteins of a sixchannels-per-pass plate heat exchanger. J. Food Eng. 34:91-108.

Fickak, A., A. Al-Raisi, and X. D. Chen. 2011. Effect of whey protein concentration on the fouling and cleaning of a heat transfer surface. J. Food Eng. 104:323-331.

Guérin, R., G. Ronse, L. Bouvier, P. Debreyne, and G. Delaplace. 2007. Structure and rate of growth of whey protein deposit from in situ electrical conductivity during fouling in a plate heat exchanger. Chem. Eng. Sci. 62:1948-1957.

Jimenez, M., G. Delaplace, N. Nuns, S. Bellayer, D. Deresmes, G Ronse, G. Alogaili, M. Collinet-Fressancourt, and M. Traisnel. 2013. Toward the understanding of the interfacial dairy fouling deposition and growth mechanisms at a stainless steel surface: A multiscale approach. J. Colloid Interface Sci. 404:192-200.

Kerche, F., M. Weterings, and M. Beyrer. 2016. The effect of temperature and shear upon technological properties of whey protein concentrate: Aggregation in a tubular heat exchanger. Int. Dairy J. 60:32-38. http://dx.doi.org/10.1016/j.idairyj.2016.02.032.

Khaldi, M., P. Blanpain-Avet, R. Guérin, G. Ronse, L. Bouvier, C. André, S. Bornaz, T. Croguennec, R. Jeantet, and G. Delaplace. 2015a. Effect of calcium content and flow regime on whey protein fouling and cleaning in a plate heat exchanger. J. Food Eng. 147:68-78.

Khaldi, M., G. Ronse, C. André, P. Blanpain-Avet, L. Bouvier, T. Six, S. Bornaz, T. Croguennec, R. Jeantet, and G. Delaplace. 2015b. Relationship between $\beta$-lactoglobulin denaturation and fouling mass distribution in a plate heat exchanger. In Heat Exchanger Fouling and Cleaning Conference, Session 9: Fouling During Food Processing, June 7-12, 2015, Enfield (Dublin), County Meath (Ireland).

Khaldi, M., G. Ronse, C. André, P. Blanpain-Avet, L. Bouvier, T. Six, S. Bornaz, T. Croguennec, R. Jeantet, and G. Delaplace. 2015c. Denaturation kinetics of whey protein isolate solutions and fouling mass distribution in a plate heat exchanger. Int. J. Chem. Eng. 2015:139638 http://dx.doi.org/10.1155/2015/139638.

Lalande, M., J.-P. Tissier, and G. Corrieu. 1985. Fouling of heat transfer surfaces related to $\beta$-lactoglobulin denaturation during heat processing of milk. Biotechnol. Prog. 1:131-139.

Oldfield, D. J., H. Singh, and M. W. Taylor. 2005. Kinetics of heat induced whey protein denaturation and aggregation in skim milks with adjusted whey protein concentration. J. Dairy Res. 72:369378. 
Petit, J., A. L. Herbig, A. Moreau, and G. Delaplace. 2011. Influence of calcium on beta-lactoglobulin denaturation kinetics: Implications in unfolding and aggregation mechanisms. J. Dairy Sci. 94:5794-5810.

Petit, J., T. Six, A. Moreau, G. Ronse, and G. Delaplace. 2013. $\beta$-lactoglobulin denaturation, aggregation and fouling in a plate heat exchanger: Pilot-scale experiments and dimensional analysis. Chem. Eng. Sci. 101:432-450.

René, F., J.-C. Leuliet, and M. Lalande. 1991. Heat transfer to Newtonian and non-Newtonian food fluids in plate heat exchangers: Experimental and numerical approaches. Trans. IChemE 69:115-126.

Rosmaninho, R., and L. F. Melo. 2006. Calcium phosphate deposition from simulated milk ultrafiltrate on different stainless steel-based surfaces. Int. Dairy J. 16:81-87.

Sadeghinezhad, E., S. N. Kazi, A. Badarudin, M. N. M. Zubair, B. L. Dehkordi, and C. S. Oon. 2013. A review of milk fouling on heat exchanger surfaces. Rev. Chem. Eng. 29:169-188.
Tolkach, A., and U. Kulozik. 2007. Reaction kinetic pathway of reversible and irreversible thermal denaturation of $\beta$-lactoglobulin. Lait $87: 301-315$.

Toyoda, I., P. J. R. Schreier, and P. J. Fryer. 1994. A computational model for reaction fouling from whey protein solutions. Pages 222 229 in Fouling and Cleaning in Food Processing Congress, Jesus College, Cambridge, 23-25 March 1994.

Van Asselt, A. J., M. M. M. Vissers, F. Smit, and P. de Jong. 2005. Inline control of fouling. In Proceedings of Heat Exchanger Fouling and Cleaning - Challenges and Opportunities, Kloster Irsee, Germany, June 5-10, (USA). Engineering Conferences International, New York, NY.

Wolz, M., and U. Kulozik. 2015. Thermal denaturation kinetics of whey proteins at high protein concentrations. Int. Dairy J. 49:95101.

Wolz, M., E. Mersch, and U. Kulozik. 2016. Thermal aggregation of whey proteins under shear stress. Food Hydrocoll. 56:396-404. 